\title{
On abnormal Carcinoscorpius rotundicauda (Latreille, 1802) (Chelicerata: Xiphosurida) from the Indian Sundarbans and possible conservation directions
}

\author{
Об аномальных Carcinoscorpius rotundicauda (Latreille, 1802) \\ (Chelicerata: Xiphosurida) из индийского Сундарбана \\ и возможкных направлениях охраны этого вида
}

\author{
Swati Das ${ }^{1,2}$, Basudev Tripathy ${ }^{1}$, K.A. Subramanian ${ }^{3}$, \\ Russell D.C. Bicknell ${ }^{4, *}$ \\ Свати Аас ${ }^{1,2}$, Басундев Трипати ${ }^{1}$, К.А. Субраминиан ${ }^{3}$, \\ P.A.K. БикнемА ${ }^{4}{ }^{*}$
}

\footnotetext{
${ }^{1}$ Zoological Survey of India, M- Block, New Alipore, Kolkata 700053, West Bengal India.

${ }^{2}$ Department of Zoology, University of Madras, Chennai 600025 India.

${ }^{3}$ Zoological Survey of India, Southern Regional Centre, 130, Santhome High Road, Chennai, Tamil Nadu 600028 India.

${ }^{4}$ Palaeoscience Research Centre, School of Environmental and Rural Science, University of New England, Armidale, New South Wales, 2351 Australia.

*Corresponding author: rdcbicknell@gmail.com; rbickne2@une.edu.au
}

KEY WORDS: Abnormalities, Xiphosura, horseshoe crabs, Carcinoscorpius rotundicauda, Indian Sundarbans, conservation.

КЛЮЧЕВЫЕ СЛОВА: Аномалии, Хiphosura, мечехвосты, Carcinoscorpius rotundicauda, индийский Сундарбан, охрана.

ABSTRACT. Xiphosurida are iconic group of marine chelicerates that have been subject to more than 200 years of neonatological and palaeontological scrutiny. However, recent studies have identified that there is very little data concerning abnormal specimens, and even less data on wild populations. The present study aims to rectify this dearth of information by documenting abnormal Carcinoscorpius rotundicauda from the Indian Sundarbans. We illustrated 36 abnormal specimens and attribute the abnormalities to injuries. Morphological differences between injured relative to noninjured individuals are considered and possible causes for injuries are discussed. Major anthropogenic threats are highlighted, with the aim of illustrating the key directions needed to conserve the unique mangrove horseshoe crab in the Indian Sundarbans.

How to cite this paper: Das S., Tripathy B., Subramanian K.A., Bicknell R.D.C. 2021. On abnormal Carcinoscorpius rotundicauda (Latreille, 1802) (Chelicerata: Xiphosurida) from the Indian Sundarbans and possible conservation directions // Arthropoda Selecta. Vol.30. No.1. P.63-88, Supplemental Data 1. doi: 10.15298/arthsel.30.1.06

РЕЗЮМЕ: Мечехвосты (Xiphosurida) - группа морских хелицеровых, которые более 200 лет служат объектом классических неонатологических и палеонтологических исследований. Тем не менее, выяснилось, что данные об аномальных экземплярах, тем более из диких популяций, крайне немногочисленны. Задача настоящей работы - пополнить недостаток информации сведениями об аномальных Carcinoscorpius rotundicauda из индийской части Сундарбана, зоны мангровых лесов в устье Ганга. Описано 36 аномальных экземлпяров, аномалии которых привязаны к определенным повреждениям. Рассмотрены морфологические различия между поврежденными и неповрежденными экземплярами, обсуждаются возможные причины повреждений. С целью иллюстрации ключевых направлений охраны уникальных мангровых мечехвостов в индийском Сундарбане особо подчеркиваются основные антропогенные угрозы в отношении этих хелицеровых.

\section{Introduction}

Xiphosurida, the so-called horseshoe crabs, are extant marine chelicerates that survived the major Phanerozoic mass extinctions [Rudkin et al., 2008; Bicknell, Pates, 2020a]. Their fossil record extends back at least 480 million years [Van Roy et al., 2010] and members of the group show little morphological change between the Jurassic and extant taxa [Bicknell et al., 2019b; Bicknell, Pates, 2020a]. Despite an exceptional palaeontological record of diversity and disparity 
[Naugolnykh, 2018; Bicknell, 2019c; Bicknell, Pates, 2020a; Bicknell et al., 2020], there are only four extant horseshoe crabs species. These are the American horseshoe crab - Limulus polyphemus (Linnaeus, 1758), a species found along the eastern North America coast - and the three species restricted to Indo-Pacific region: Tachypleus tridentatus (Leach, 1819), T. gigas (Müller, 1785), and Carcinoscorpius rotundicauda (Latreille, 1802) [Shuster Jr., 1982]. The north-eastern Indian coast is a preferred breeding and spawning ground for $T$. gigas and $C$. rotundicauda. These cooccurring species have a distribution from the West Bengal to Odisha coasts, and possibly into the northern Andhra Pradesh [Tripathy et al., 2018]. Of these areas, the Odisha coast represents the main habitat for horseshoe crabs in India, especially $T$. gigas. This region has therefore been more thoroughly studied than the West Bengal population (Table 1).

The world's largest mangrove delta - the Indian Sundarbans - represents a dynamic ecosystem that covers $9630 \mathrm{~km}^{2}$ and is characterised by innumerable rivers, rivulets, creeks, river estuaries, and unique salt tolerant mangrove trees like Avicennia sp., Bruguiera sp., Rhizophora sp., Ceriops sp., and is an environment where fresh- and seawater regular mix [Nandi et al., 2015]. The Indian Sundarbans are located within the Bay of Bengal, a delta where the Ganges, Brahmaputra and Meghna rivers terminate; extending from southwest Bangladesh to south West Bengal [Ghosh et al., 2015]. The Indian Sundarbans mudflats represent ideal conditions for juvenile horseshoe crabs to forage and therefore breeding grounds [Sekiguchi et al., 1988; Chen et al., 2004; Almendral, Schoppe, 2005]. As such, both Carcinoscorpius rotundicauda and Tachypleus gigas are known to the Indian Sundarbans mudflats [Tripathy et al., 2018]. Of these two, C. rotundicauda is more common, but has been understudied, despite the iconic nature of horseshoe crabs in general (Table 1). This is striking as C. rotundicauda is unique amongst extant xiphosurids: it is the smallest species (average adult size 28.0-33.5 cm long), can inhabit freshwater and marine conditions, and spawns in the mangroves.

Research into horseshoe crab ecology has recently turned to consider injuries and other abnormal developments. Understanding abnormalities can inform our understanding of recovery from injuries and present insight into poor environmental or ecological conditions [Bicknell, Pates, 2019a]. Presently, the key studies of abnormal xiphosurids are van der Meer Mohr [1935], Shuster Jr. [1982], Jell [1989], Bicknell et al. [2018], and Bicknell \& Pates [2019a]. However, most of these studies have considered museum collections and only Bicknell \& Pates [2019a] documented abnormal Carcinoscorpius rotundicauda specimens. To develop this research trend, we examine live abnormal $C$. rotundicauda and consider the probable causes thereof. We illustrate the main anthropogenic threats require mitigation for effective conservation of $C$. rotundicauda within the Indian Sundarbans.

\section{Studied Region}

The Bengal Plain of India is characterised by extensive coastal tract bordered by the southern Bay of Bengal and is the world's largest active delta [Umitsu, 1993; Rudra, 2014; Jana, 2019] and formed during the last 11,000 years [Kuehl et al., 2005; Mikhailov, Dotsenko, 2007; Jana, 2019]. It consists of two contrasting coastal environments: the macro-tidal Hooghly estuary and the mesotidal Midnapore Coastal plain [Mondal et al., 2015]. Within Indian Sundarbans, there are 102 islands, 54 of which have human habitation and the other 48 are covered by mangrove forest [Nandi et al., 2015]. Our study was conducted in two main areas within the Indian Sundarbans in the South 24 Parganas district of West Bengal: Sagar Island and Patiboni in Frezerganj (Fig. 1). Sagar Island is the largest island of the Sundarban deltaic complex and characterised by numerous tidal creeks, canals, mud flats/salt marshes, mangroves, and sandy beaches/dunes. The Patiboni area in Frezerqani is located east of Sagar Island and has a sandier substrate than Sagar Island. These two areas were selected as study sites as they both have significant mangrove cover. Neither the Royal Bengal Tiger (Panthera tigris tigris) nor salt water crocodiles (Crocodylus porosus) are known to these areas, and these regions are outside protected area boundaries.

\section{Methods and Materials}

A field survey was conducted between March 2019 and July 2020. Specimens were identified during full and new moon periods to maximise the exposed intertidal zone. Four sites on Sagar Island were selected: Koshtola, Krishnanagar, Bankimnagar, and Mayagoalinir Ghat. The Frezerganj surveys were conducted about Patibonia. Study areas were divided into ten $100 \mathrm{~m} \mathrm{x}$ $100 \mathrm{~m}$ grids. Each grid was randomly sampled for horseshoe crabs for $\sim 20$ minutes. Size measurements and the gender of any identified specimens were gathered for Supplemental Data 1 (see Fig. 2 for gathered measurements). Occasionally, the complete suite of measurements could not to be gathered, reflecting constraints on data collection time. When abnormal individuals were identified, the GPS location, size data, and abnormality data were documented. Amplexed pairs were noted, but morphometric and injury data were only gathered if the pair separated. Abnormal individuals were photographed with a Nikon 5600 DSLR (18-55 $\mathrm{mm}$ or $75-300 \mathrm{~mm}$ lens). Photographs were stacked using Adobe Photoshop 7.0 software. Five abnormal specimens were collected for this study and placed in $70 \%$ ethanol solution for photography in lab with a Nikon 5600 DSLR (18-55 mm lens). Specimens were considered abnormal if they had deformed/missing exoskeleton sections, malformed growths and generally non-standard exoskeletal morphologies [sensu Owen, 1985; Bicknell et al., 2018; Bicknell, Pates, 2019a, 
On abnormal Carcinoscorpius rotundicauda from the Indian Sundarbans

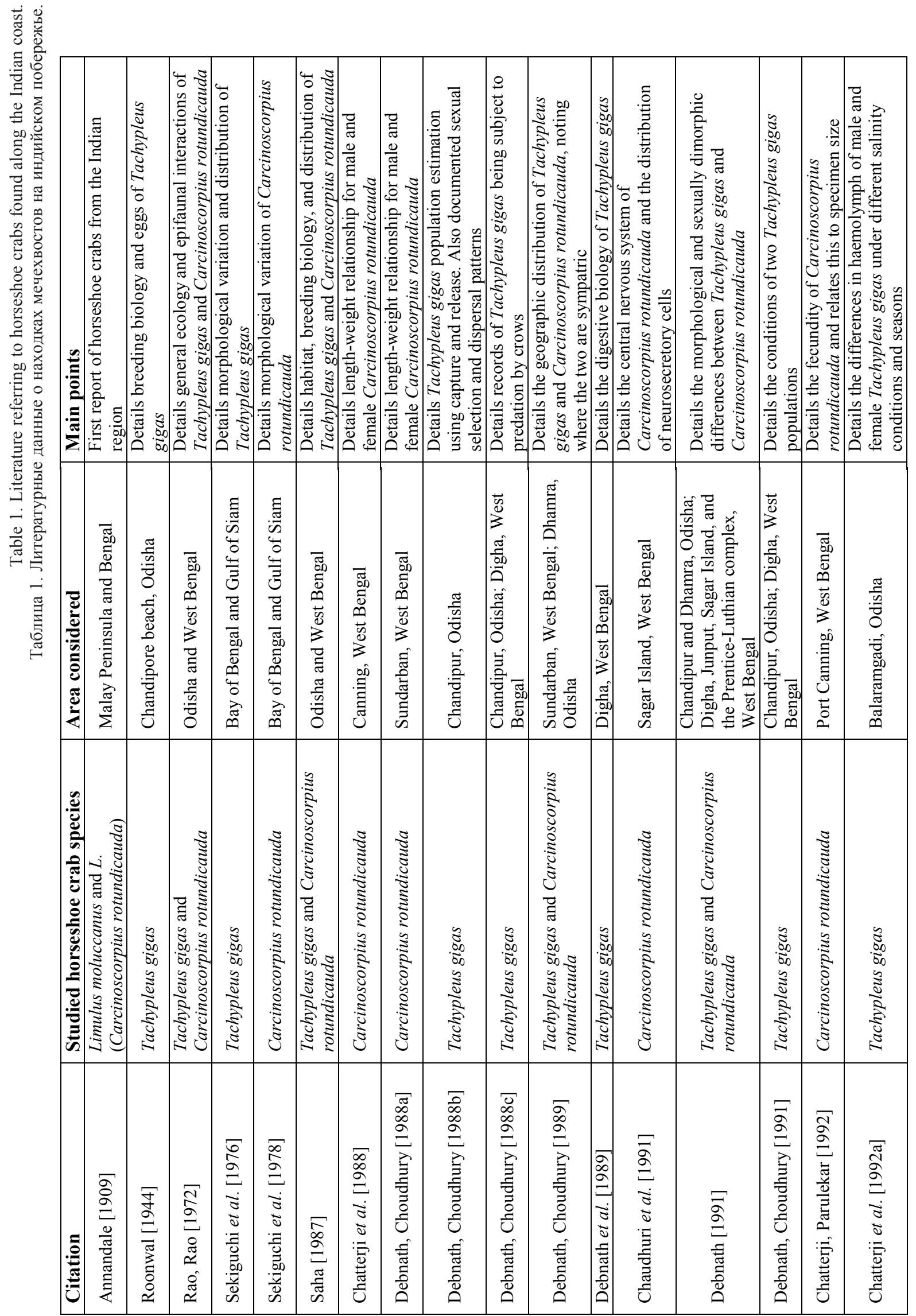



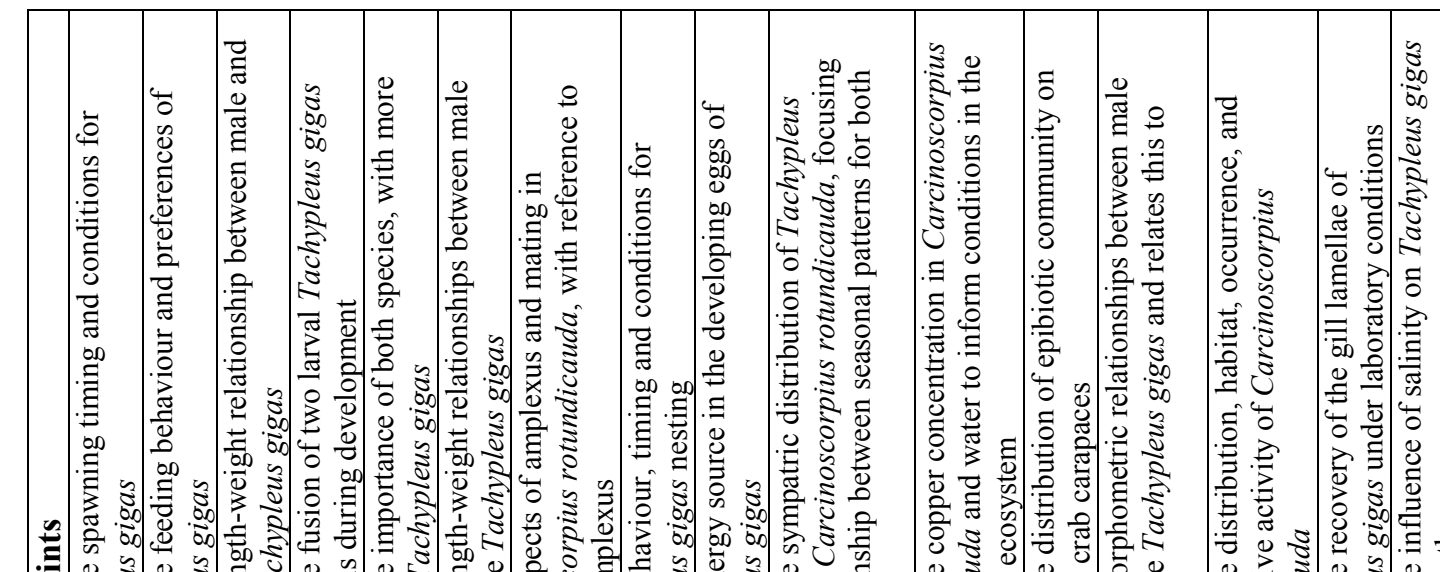

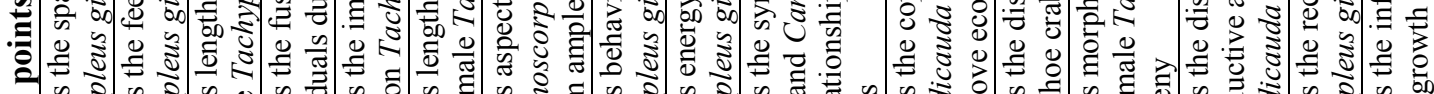

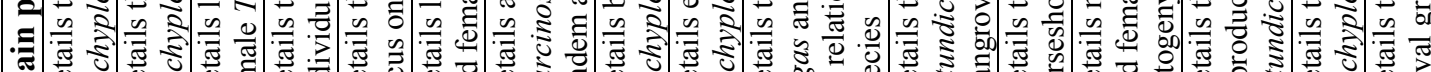

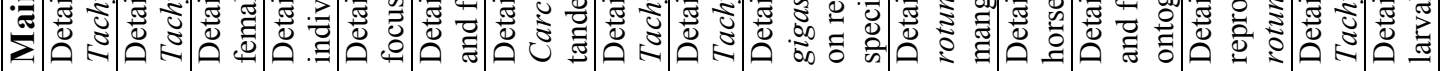

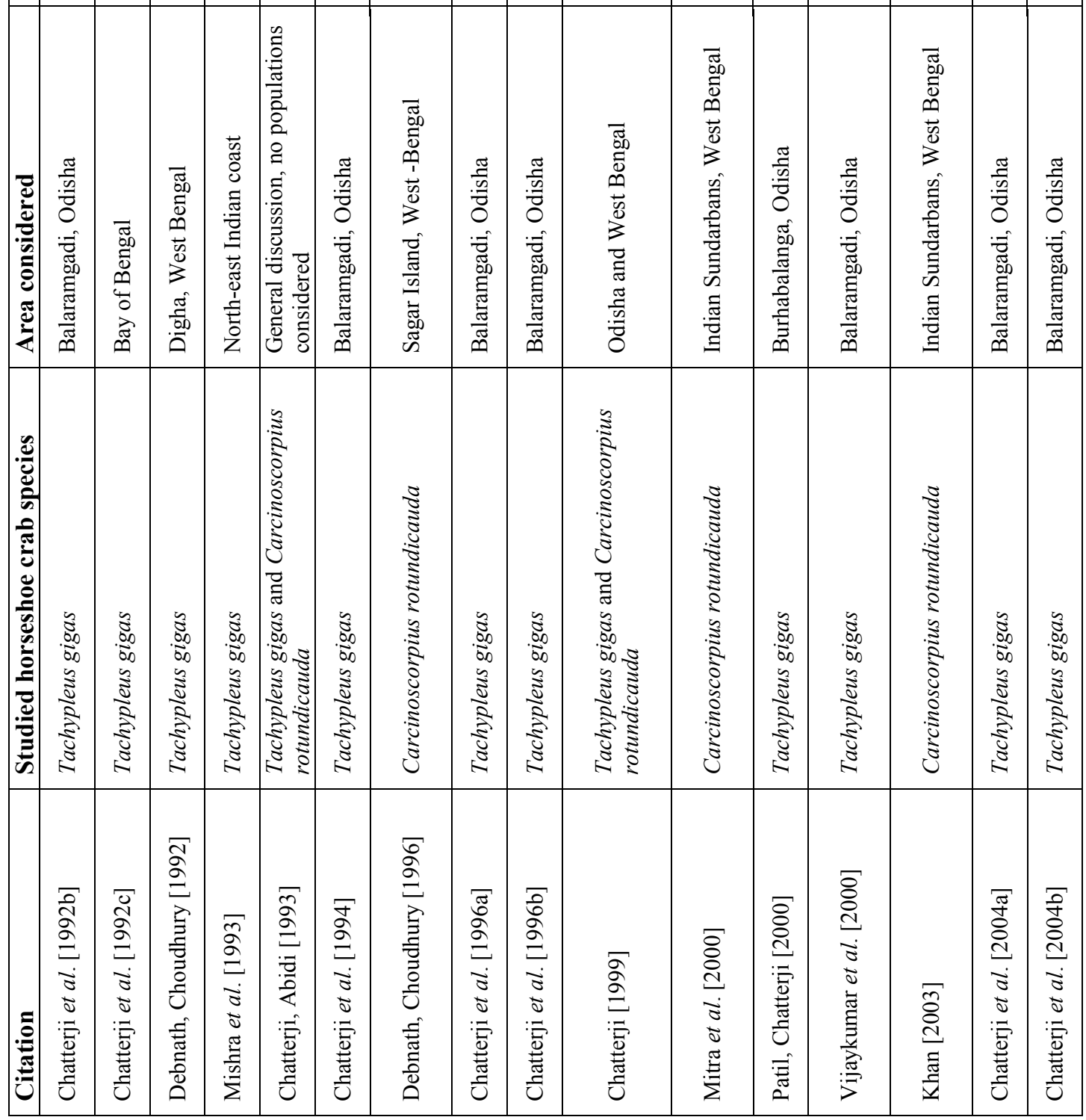


On abnormal Carcinoscorpius rotundicauda from the Indian Sundarbans

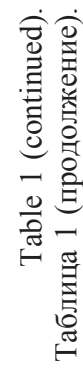

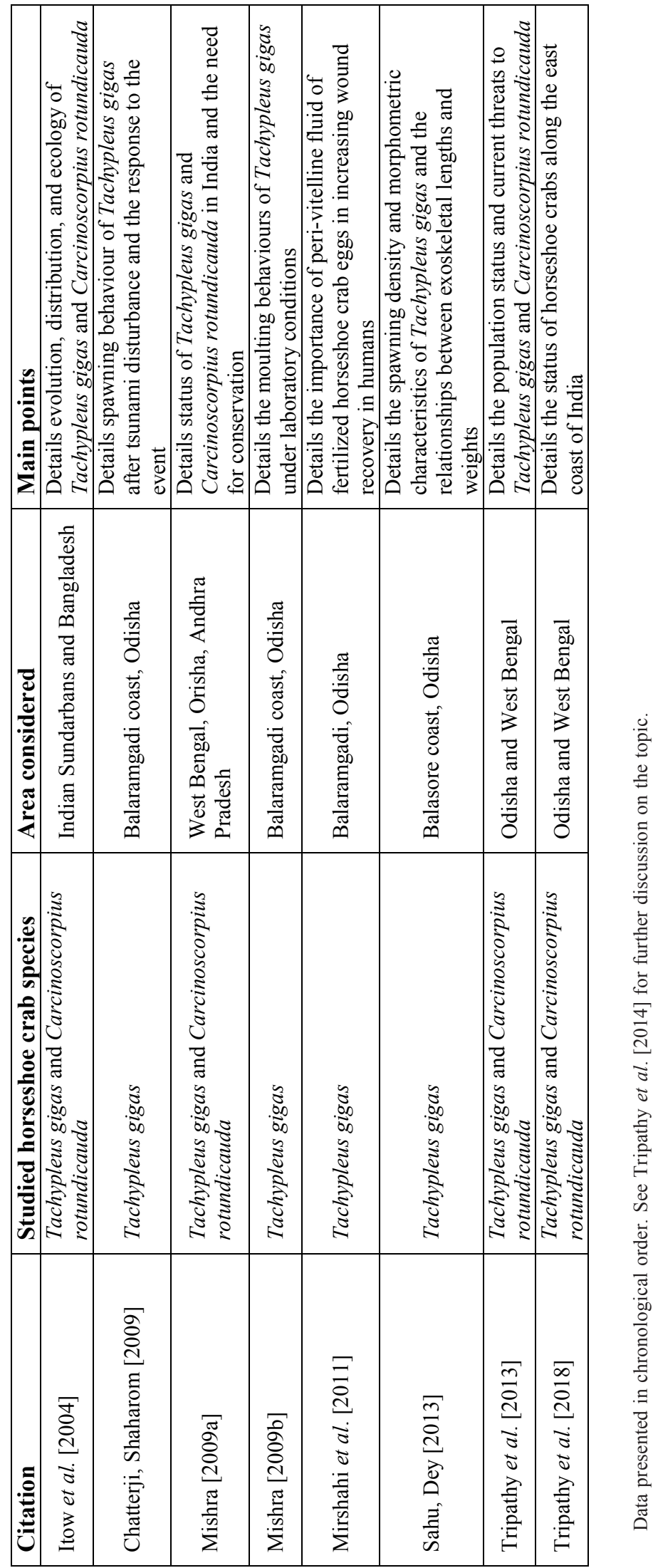




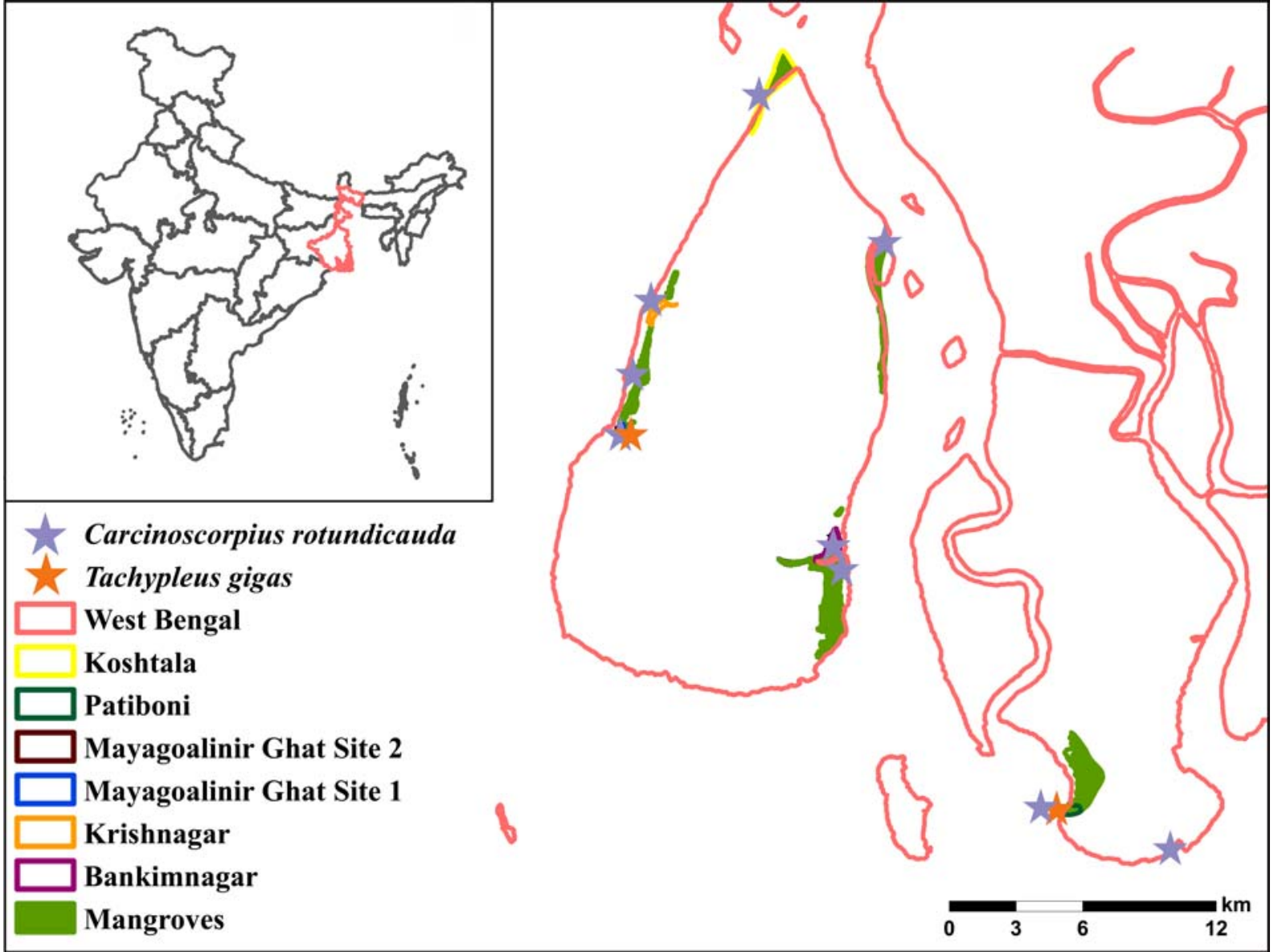

Fig. 1. Study area map showing distribution of horseshoe crabs. Studied area has been colour coded for regions and locations of mangrove development.

Рис. 1. Карта области исследования, показывающая распространение мечехвостов. Цветом выделены регионы и места развития мангров.

2020b; Bicknell, Holland, 2020]. Only five abnormal specimens were collected for in-lab consideration as we wanted to avoid impacting the already fragile population. Anthropological activities at study sites were documented to illustrate possible human influences on the population. The dataset of measurements and injured/not injured specimens were plotted to determine whether patterns injury was influenced by size or gender. Supplemental Data 1 were imported into R [R Core Team, 2020] and the measurements were log normalised to account for allometry within the population. The log normalised data for prosomal (=cephalothoracic) and thoracetronic (=opistosomal) measurements were plotted. Plots were colour coded for injured and non-injured specimens and for the gender/ juvenile assignment.

\section{Results}

A total of 46 abnormal Carcinoscorpius rotundicauda individuals (18 adult males, 18 adult females and 10 juveniles) were identified within the sampled
181 specimens (87 females, 63 males and 31 juveniles). The most common abnormalities were prosomal $(n=19)$, thoracetronic $(n=15)$, and telsonic $(n=10)$. There were rare examples of lateral compound eye $(n=3)$ and appendage $(n=2)$ abnormalities. The majority of abnormal individuals were located in the Patiboni area $(n=17)$, Bankimnagar $(n=13)$, and Mayagoalinir Ghat $(n=10)$; with limited numbers in Kashtola $(n=5)$ and Beguakhali $(n=1)$. A large selection $(n=36)$ of the abnormal specimens are figured and described below (Figs 3-17).

An adult female with a malformed prosoma (Fig. $3 \mathrm{~A}-\mathrm{C})$. An indentation slightly posterior to the anterior-most section of the prosomal rim and malformed genal spines are observed. The left genal spine is rounded, while the right genal spine has two 'U'-shaped indentations.

A juvenile specimen with a deformed thoracetron (Fig. 3D-F). On the left pleural lobe, the two posteriormost moveable and fixed spines are missing. On the right pleural lobe, the third moveable spine is missing, but the fixed spines are present and not malformed. 


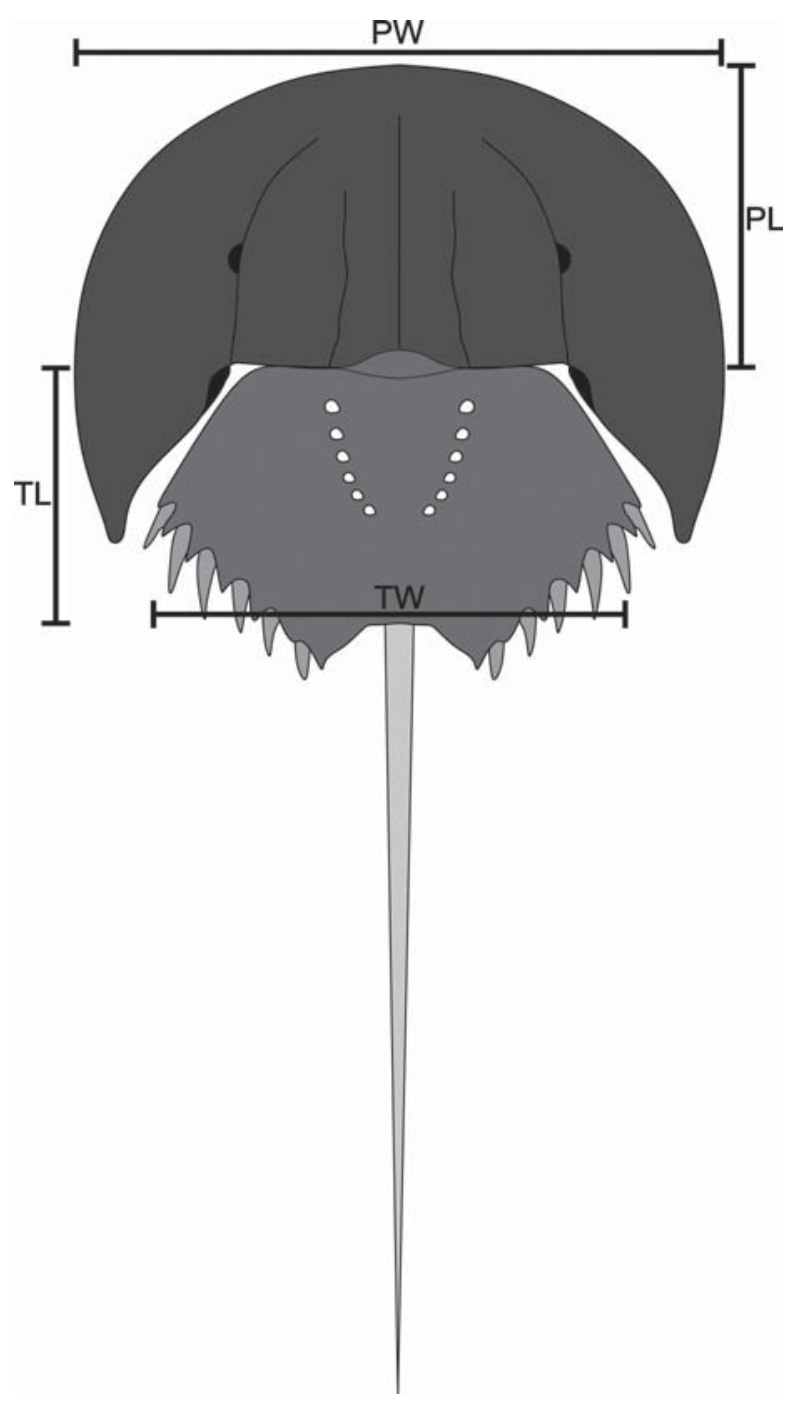

Fig. 2. Line drawing of measurements taken from the sampled Carcinoscorpius rotundicauda specimens. Acronyms: PW prosomal width, PL — prosomal length, TL — thoracetron length, TW - thoracetron width.

Рис. 2. Схема промеров образуов Carcinoscorpius rotundicauda. Сокращения: PW - ширина просомы, PL - длина просомы, TL - длина торацетрона (заднего отдела тела), TW ширина торацетрона (заднего отдела тела).

An adult female with a malformed right genal spine and two abnormalities on the thoracetron (Fig. 4A-D). The distal edge of the genal spine is rounded and there are multiple rounded bulges on the dorsum of the spine. The left thoracetronic pleural lobe shows two movable spines within the same spine notch. Furthermore, the three posterior-most spines on the left pleural lobe are stunted, showing reduced fixed spines and associated notches. The right pleural lobe has five movable spines and the posterior-most movable spine, and associated spine notch, are absent.

A juvenile with malformed genal spines (Fig. 4E$\mathrm{G})$. There is a ' $U$ '-shaped indentation on both genal spines, proximal to the ophthalmic ridges. A scar ex- tending into the left genal spine is also noted. A hole is present on right genal spine, near the ' $U$ '-shaped indentation.

An adult male with a highly malformed genal spine and thoracetron (Fig. 5A, B). Left genal spine has a serrated border proximal to the thoracetron and at least three ' $V$ '-shaped indentations. Left lateral compound eye is damaged. The left thoracetronic pleural lobe lacks anterior movable spines and associated spine notches. The border of this section is smooth and potentially cicatrised. Posterior movable spines are either shortened, or absent.

An adult female with a malformed prosomal rim, thoracetronic border and telson (Fig. 5C-E). The prosomal rim has multiple shallow ' $U$ '-shaped indentations on the right side. These indentations extend into the right genal spine tip. Telson is short, blunt and has a cicatrised hole within the last fifth of the spine length. Posterior movable spines on both thoracetronic pleural lobes are missing and terminal thoracetronic spines are stunted.

A large adult female with a distorted prosoma (Fig. 5F). The prosoma appears to be completely collapsed from the left ophthalmic ridge through to the anterior border on the right side.

An adult male with a malformed prosoma and telson spine (Fig. 5G). The anterior prosomal rim on the ventral side has a circular depression anterior to the mesial spine. This same specimen lacks a telson.

An adult male specimen with a malformed prosoma and telson (Fig. 6A). The right prosomal rim has and multiple ' $\mathrm{V}$ '- and ' $\mathrm{W}$ '-shaped indentations along the border. This specimen also has a twisted telson that is kinked towards the specimens' dorsum.

An adult female specimen with a severely damaged left prosoma and thoracetron (Fig. 6B, C). The left genal spine shows extensive cicatrised along the posterior border and is missing the left lateral compound eye. Anterior section of thoracetron shows a 'W'-shaped abnormality with a cicatrised edge and butterfly spawning scars.

A male with a malformed prosoma and thoracetron on the right side (Fig. 6D, E). The thoracetron has a large, irregular section removed that is not cicatrised and a hole within the posterior quarter. Recovered holes are noted on the right ophthalmic ridge, proximal to the prosomal-thoracetron hinge.

A juvenile specimen with malformations on both thoracetronic pleural lobe (Fig. 6F). On the right side, all movable spines and associated spine notches are absent. 'W'- and ' $\mathrm{V}$ '-shaped indentations are also present. On the left pleural lobe, the posterior section lacks moveable spines and there is a deep ' $\mathrm{V}$ '-shaped indentation. Furthermore, the telson is shorter and more blunt than would be expected for a specimen this size.

An adult male with a deformed genal spine on the left side (Fig. 7A, B). The genal spine is blunt and has a ' $\mathrm{V}$ '-shaped indentation proximal to the sagittal line of the individual. 

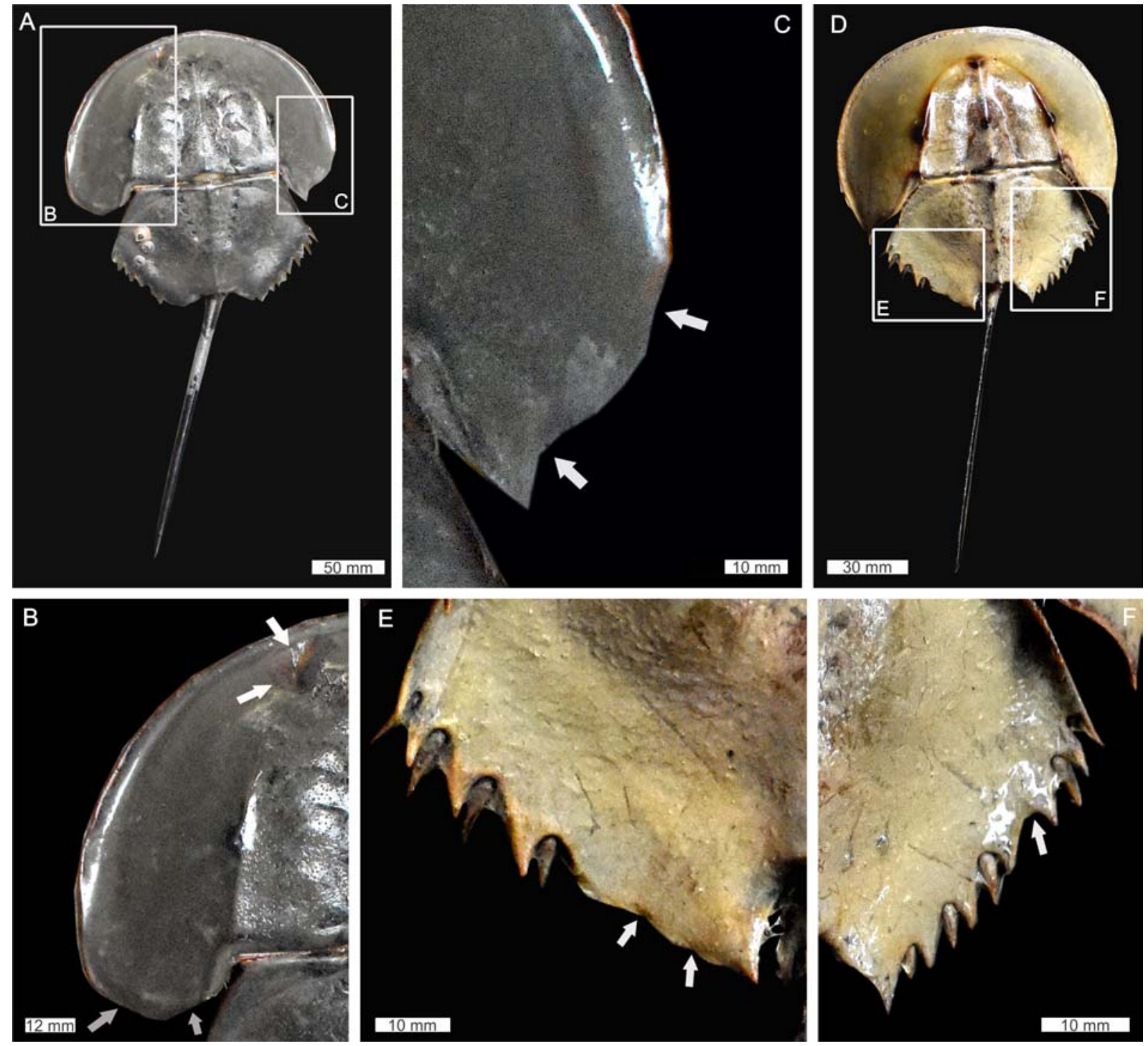

Fig. 3. Carcinoscorpius rotundicauda with prosomal and thoracetronic abnormalities. A-C - an adult female from the Patiboni region with malformed prosoma: A - complete specimen; B — close-up of malformations on the left prosomal side. An indentation is observed near anterior prosomal rim (white arrows) and the genal spine is rounded compared to the right side (grey arrows); C — close-up of right genal spine showing ' $U$ '-shaped indentations (white arrows). D-F - juvenile from the Patiboni region with abnormal movable spines: D — complete specimen; E — close-up of missing moveable spines on the left side (white arrows); F — close-up of missing moveable spine on the right side (white arrow).

Рис. 3. Carcinoscorpius rotundicauda с аномалиями просомы и торацетрона. А-C - взрослая самки из района Патибони с просомой неправильной формы: А - экземпляр целиком; В - деформация левой стороны просомы крупным планом. Наблюдается вдавление около переднего края просомы (белые стрелки) и щёчный угол закруглен по сравнению с правой стороной (серые стрелки); C — крупный план правого щёчного угла, показаны 'U'-образные вдавления (белые стрелки). D-F — ювениль из района Патибони и аномальными подвижными шипами: D - экземпляр целиком; E — крупный план отсутствующих подвижных шипов на левой стороне (белые стрелки); F — крупный план отсутствующего подвижного шипа на правой стороне (белая стрелка).

An adult male with a malformed left genal spine (Fig. 7C, D). There are two ' $\mathrm{V}$ '- shaped indentations along the genal spine length. A 'U'-shaped indentation is noted on the posterior border of the spine, proximal to the body.

A juvenile specimen with a deformed right thoracetronic pleural lobe (Fig. 7E, F). The lobe lacks anterior movable spines and associated spine notches. The malformed border is cicatrised and lacks indentations. The posterior-most movable spines are stunted and all show a kink half way along the spine length.

An adult male with three prosomal abnormalities (Fig. 8A-D). The left anterior side shows a 'U'-shaped indentation with exoskeletal breakage. A hole is noted in the exoskeleton proximal to the prosomal-thoracetron hinge, suggesting carapace decay. A 'U'-shaped inden- 

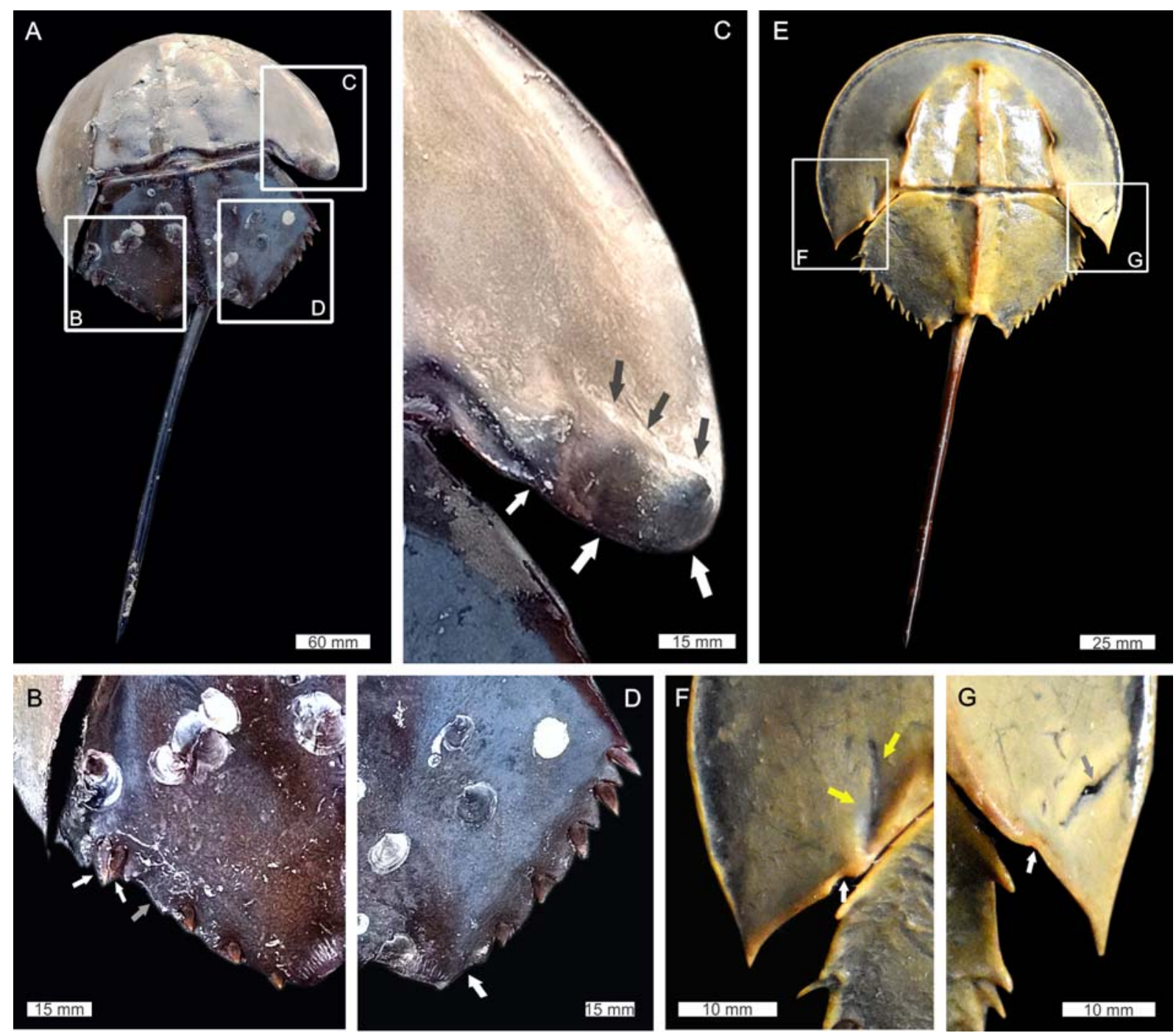

Fig. 4. Carcinoscorpius rotundicauda with prosomal and thoracetronic abnormalities. (A-D): - adult female from the Patiboni region with malformed right genal spine and thoracetron: A - complete specimen; B — close-up of left thoracetronic pleural lobe showing two movable spines present within the same spine notch (white arrows) and stunted/missing moveable spines (grey arrow); C — close-up of right genal spine showing rounded edge (white arrows) and bulges on the dorsum (grey arrows); D — close-up of right thoracetronic pleural lobe showing missing movable spines (white arrow). $\mathrm{E}-\mathrm{G}$ - juvenile from the Patiboni region with malformed genal spines: E complete specimen; F — close-up of 'U'-shaped indentation (white arrow) and scar (yellow arrows) on the left genal spine; G — close-up of ' $U$ '-shaped indentation (white arrow) and hole (grey arrow) on the right genal spine.

Рис. 4. Carcinoscorpius rotundicauda с аномалиями просомы и торацетрона. (A-D): - взрослая самка из района Патибони с неправильными правым щёчным углом и торацетроном: А - экземпляр целиком; В — крупный план левой плевральной доли торацетрона, показаны два подвижных шипа в одной выемке (белые стрелки) и уменьшенные/отсутствующие подвижные шипы (серая стрелка); C - крупный план правого щёчного угла, показан закругленный край (белые стрелки) и выпуклости на дорсуме (серые стрелки); D - крупный план правой плевральной доли торацентрона, показаны отсутствующие подвижные шипы (белая стрелка). E-G - ювениль из района Патибони с видоизмененными щёчными углами: Е — экземпляр целиком; F — крупный план 'U'-образного вдавления (белая стрекла) и рубца (желтые стрелки) на поверхности левого щёчного угла; $\mathrm{G}$ - крупный план 'U'образного вдавления (белая стрелка) и углубления (серая стрелка) на поверхности правого щёчного угла.

tation in the posterior side of the right genal spine. There is exoskeletal deformation about this indentation, suggesting possible injury during a post-moult stage.

An adult female with thoracetronic and telson abnormalities (Fig. 8E, F). The distal section of the telson is broken and rounded. Butterfly spawning scars are noted half way along thoracetronic midline.
An adult female with genal spine and thoracetronic abnormalities (Fig. 9A-D). The right genal spine is truncated and rounded. Distal edge has a slight ' $U$ 'shaped indentation and the area proximal to the midline has a pronounced ' $\mathrm{V}$ '-shaped indentation. Genal spine point shows evidence of recovering but is more rounded than the left genal spine. Both the thoracetronic pleural lobes have stunted fixed and move- 

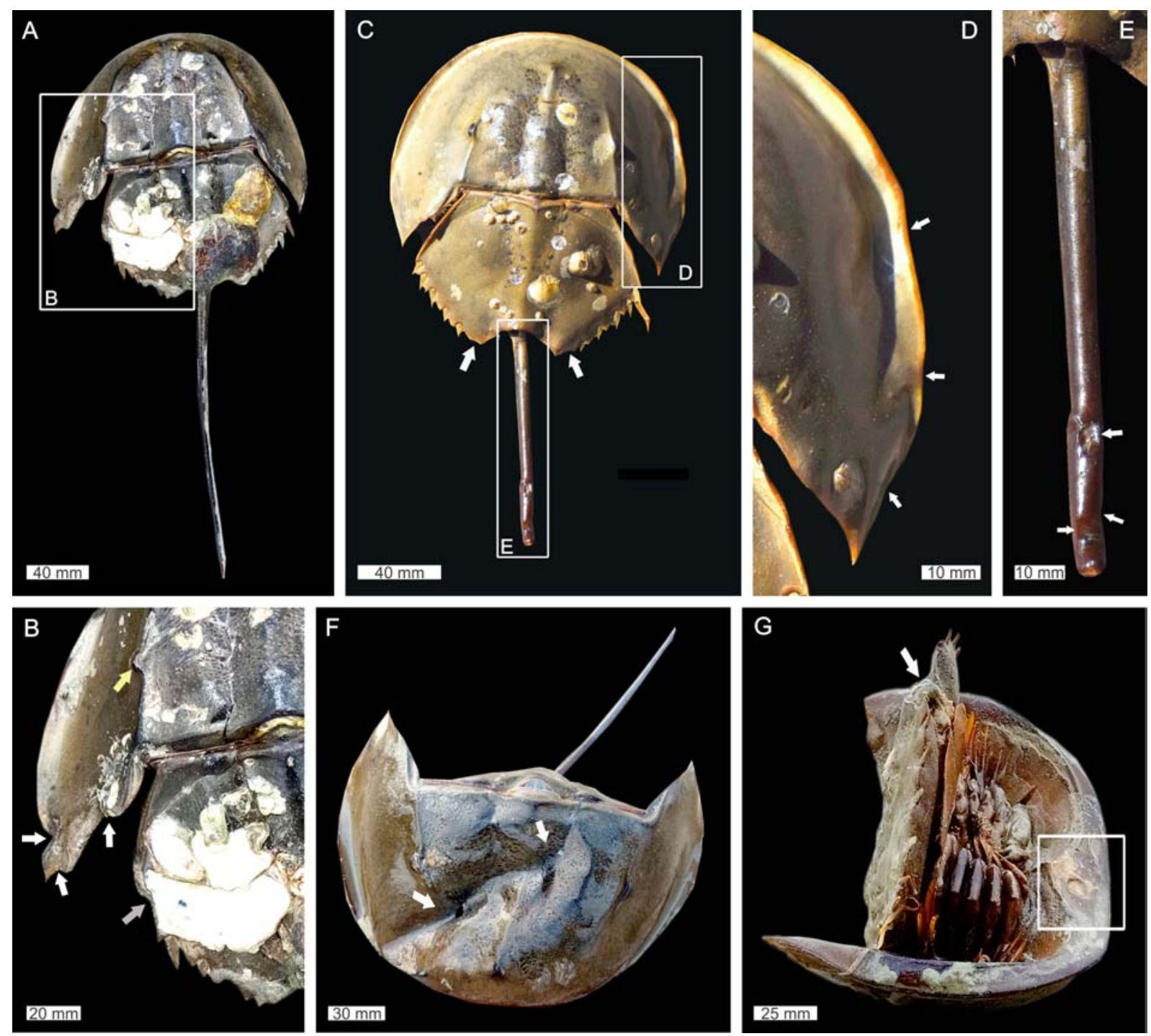

Fig. 5. Carcinoscorpius rotundicauda with prosomal, thoracetronic, and telson abnormalities. A, B - adult male from the Mayagoalinir Ghat region with highly malformed genal spine and thoracetronic abnormalities: A — complete specimen; B — close-up of injured lateral compound eye (yellow arrow), a serrated genal spine border (white arrows) and a 'V'-shaped indentation with missing movable spines (grey arrow). $\mathrm{C}-\mathrm{E}$ - adult male from the Patiboni region with prosomal, thoracetronic, and telson abnormalities: $\mathrm{C}$ - complete specimen detailing thoracetronic injuries (white arrows); D - close up of multiple ' $U$ '-shaped indentations on right side of prosoma (white arrows); E - close-up of stunted telson (white arrows); F — adult female from the Bankimnagar region with distorted prosoma (white arrows); G — adult male from the Mayagoalinir Ghat region in ventral view with circular depression in prosoma (box) and heavily reduced telson spine (white arrow).

Рис. 5. Carcinoscorpius rotundicauda с аномалиями просомы, торацетрона и тельсона. А, В - взрослая самка из района Mayagoalinir Ghat c сильно измененным щёчным углом и аномалиями торацетрона: A - экземпляр целиком; В - крупный план поврежденного бокового сложного глаза (желтая стрелка), зубчатый край щёчного угла (белые стрелки) и 'V'-образное вдавление с отсутствующими подвижными шипами (серая стрелка). С-E - взрослый самец из района Патибони с аномалиями просомы, торацетрона и тельсона: C - экземпляр целиком, показаны повреждения торацетрона (белые стрелки); D - крупный план множественных 'U'-образных вдавлений на правой стороне просомы (белые стрелки); Е — крупный план уменьшенного тельсона (белые стрелки); $\mathrm{F}$ - взрослая самка из района Банкимнагар с искривленной просомой (белые стрелки); $\mathrm{G}$ - взрослый самец из района Mayagoalinir Ghat вентрально с округлым углублением на просоме (обведено квадратом) и сильно редуцированным шипом тельсона (белая стрелка).

able spines. Furthermore, there is overlap between the second and third fixed spines on the right pleural lobe.

A juvenile specimen with a malformed telson (Fig. 9E). The telson has a bend half way along the telson spine.
An adult male with an abnormal right thoracetron and telson (Fig. 10A-C). The right thoracetronic pleural lobe has a large ' $U$ '-shaped indentation that is showing limited cicatrisation along the posterior margin. The telson is curved to the right and with increased truncation in the last fifth of spine length. 

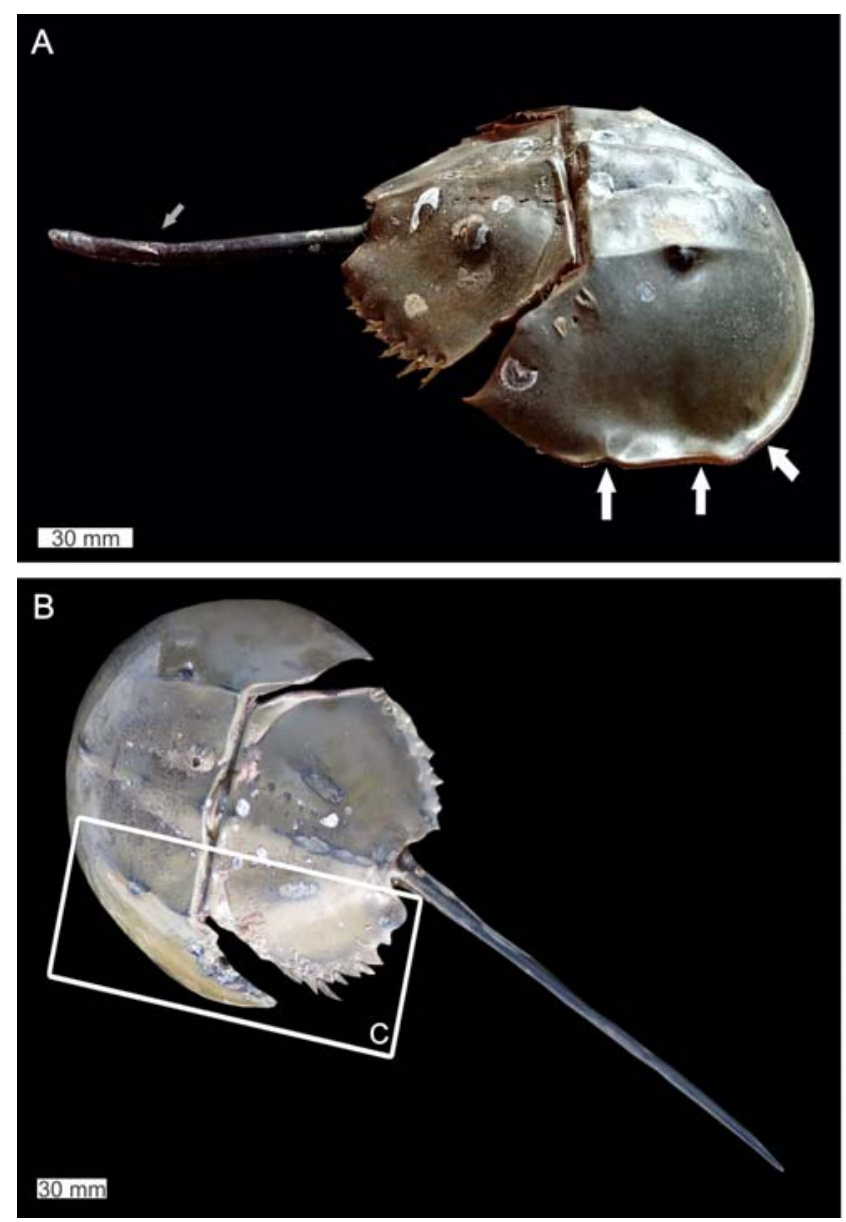
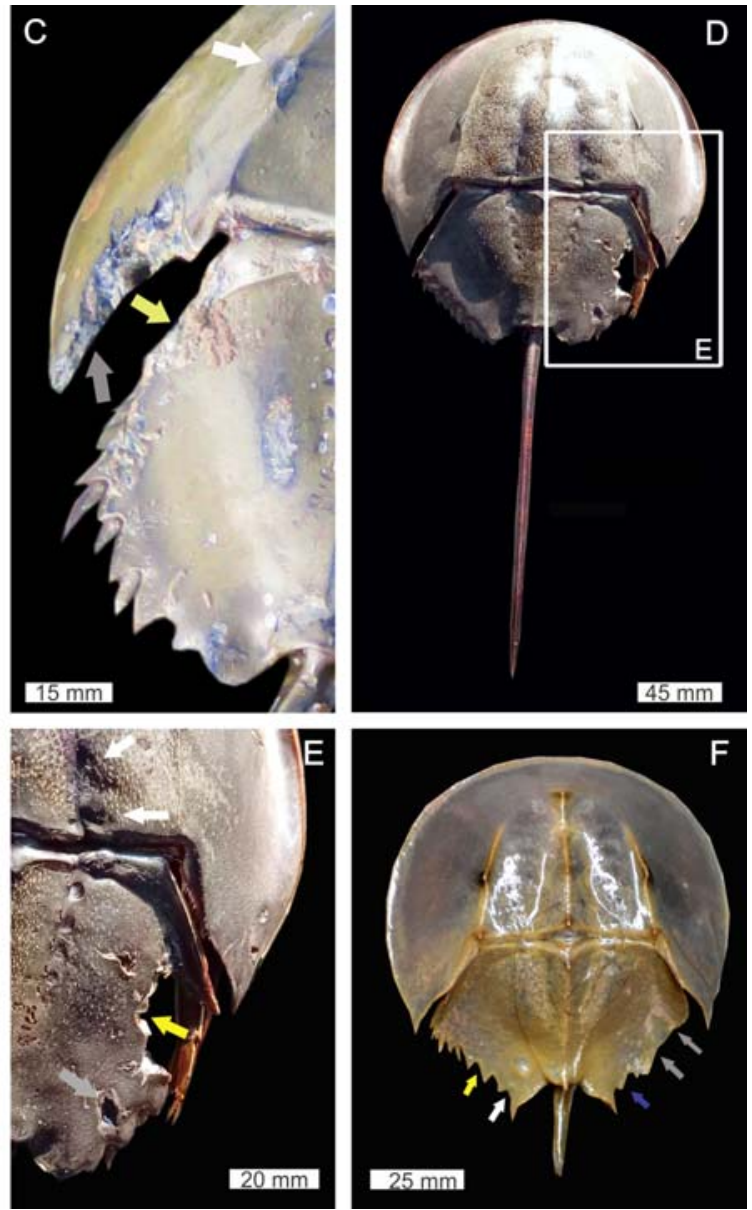

Fig. 6. Carcinoscorpius rotundicauda with prosomal, thoracetronic, and telson abnormalities. A - adult male from the Patiboni region with prosoma exhibiting multiple "V"-shaped injuries (white arrows) and a malformed telson (grey arrow). B, C - adult female from the Mayagoalinir Ghat region with damaged left prosomal side: B - complete specimen; C - close-up of the abnormalities. The left lateral compound eye is damaged (white arrow), the genal spine has a damaged and cicatrised posterior border (grey arrow) and the thoracetronic pleural lobe has a 'W'-shaped abnormality (yellow arrow). D, E - adult male from the Patiboni region with malformed right prosomal and thoracetronic side: D - complete specimen; E - close-up of malformations showing recovering holes on the right ophthalmic ridge (white arrows), the hole in the thoracetron (grey arrow) and the thoracetronic section that appears to have been removed (yellow arrow). F - juvenile specimen from the Patiboni region with malformed thoracetron and telson. Right thoracetronic pleural lobe has 'W'- and ' $\mathrm{V}$ '-shaped indentations (grey arrows) and missing movable spines (blue arrow). Left thoracetronic pleural lobe has ' $\mathrm{V}$ 'shaped indentation and missing movable spines (yellow arrow).

Рис. 6. Carcinoscorpius rotundicauda с аномалиями просомы, торацетрона и тельсона. А - взрослый самец из района Патибони с просомой с множественными 'V”-образными повреждениями (белые стрелки) и деформированным тельсоном (серая стрелка). В, C - взрослая самка из района Mayagoalinir Ghat с поврежденным левым краем просомы: В - экземпляр целиком; С крупный план аномалий. Левый боковой сложный глаз поврежден (белая стрелка), шёчный угол с поврежденным и зарубцованным задним краем (серая стрелка) с плевральная доля торацетрона имеет 'W'-образную аномалию (желтая стрелка). D, E - взрослый самец из района Патибони с видоизмененной правой стороной просомы и торацетрона: D — экземпляр целиком; Е — крупный план видоизменений, показаны восстанавливающиеся углубления на правом глазном гребне (белые стрелки), углубление в торацетроне (серая стрелка) и часть торацетрона, которая оказалась удаленной (желтая стрелка). F - ювенильный экземпляр из района Патибони с видоизмененными торацетроном и тельсоном. Правая плевральная доля торацетрона имеет 'W'- и 'V'образные вдавления (серые стрелки) и отсутствующие подвижные шипы (синяя стрелка). Левая плевральная доля торацетрона с ' $\mathrm{V}$ '-образным вдавлением и отсутствующими подвижными шипами (желтая стрелка).

An adult male with a malformed prosomal shield and thoracetron (Fig. 10D-F). Left prosomal side has a ' $\mathrm{V}$ '-shaped indentation that slightly deforms the exoskeleton. The left thoracetronic pleural lobe has three types of abnormalities. The free lobe is folded back over itself, the anterodistal section of the pleural lobe lacks any movable and fixed spines, and the posterior three movable spines are stunted.
An adult male with a malformed thoracetron and telson (Fig. 11A-D). The moveable and fixed spines on both thoracetronic pleural lobes are either stunted or entirely missing. This is especially notable in the more posterior sections. The telson is stunted, with a rounded terminus and is curved to the right. A small projection is noted where the curve begins. 

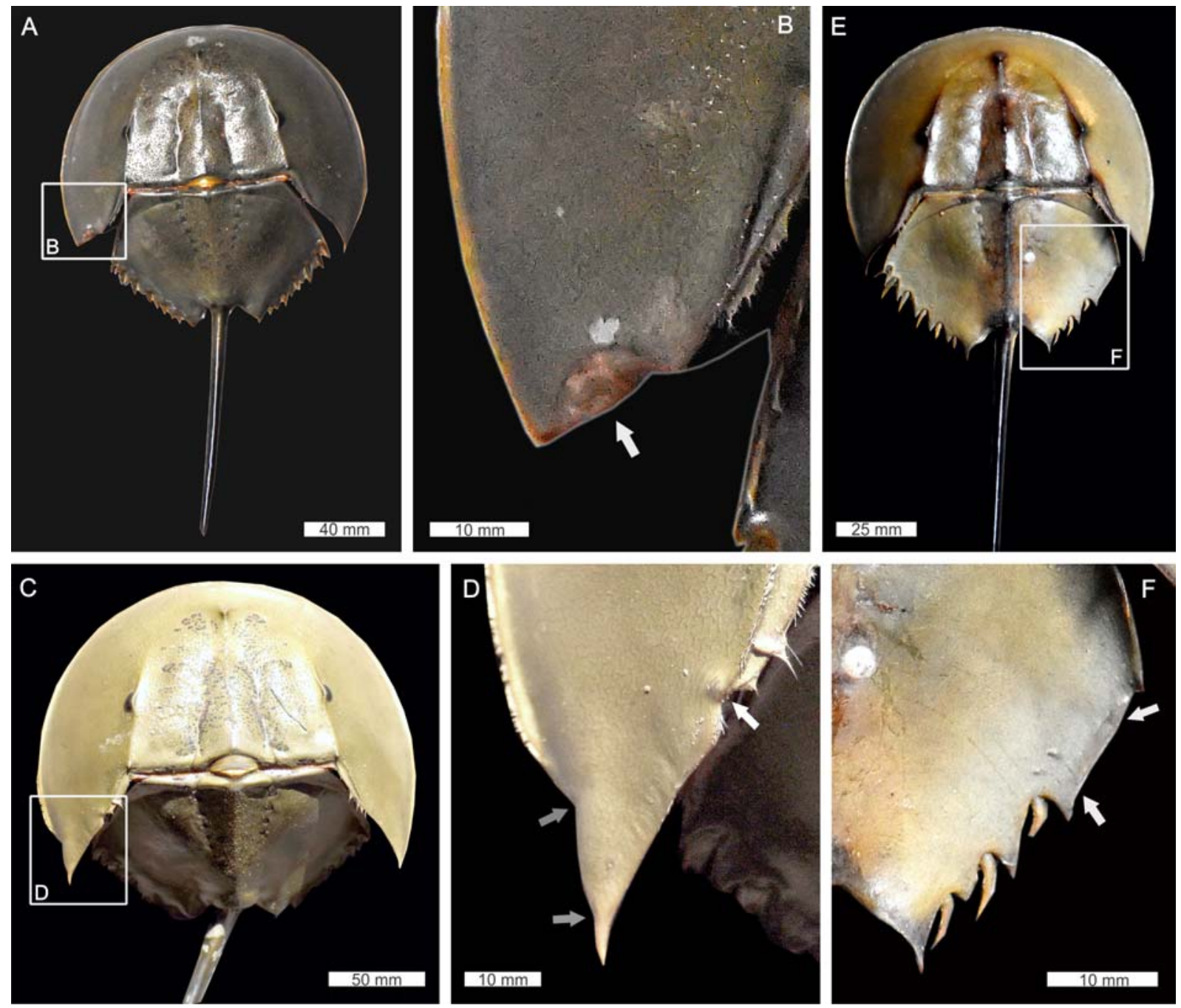

Fig. 7. Carcinoscorpius rotundicauda with prosomal and thoracetronic abnormalities. A, B - adult male from the Patiboni region with malformed left genal spine: A - complete specimen; B - close-up of blunt left genal spine with ' $\mathrm{V}$ '-shaped indentation (white arrow). C, D - adult male from Patiboni region with malformed left genal spine: C — complete specimen; D — close-up of 'U'-shaped (white arrow) and ' $\mathrm{V}$ '-shaped (grey arrows) indentations. E, F - juvenile from the Patiboni region with thoracetronic abnormalities: E complete specimen; F - close-up of right thoracetronic pleural lobe showing cicatrised border (white arrows) and stunted movable spines.

Рис. 7. Carcinoscorpius rotundicauda с аномалиями просомы и торацетрона. А, В - взрослый самец из района Патибони с видоизмененным левый щёчным углом: А - экземпляр целиком; В - крупный план притупленным левый щёчным углом с ' $\mathrm{V}$ 'образным влавлением (белая стрелка). C, D — взрослый самец из района Патибони с видоизмененным левым щёчным углом: $\mathrm{C}-$ экземпляр целиком; D - крупный план 'U'-образного (белая стрелка) и 'V'-образных (серые стрелки) вдавлений. Е, F — ювениль из района Патибони с аномалиями торацетрона: $\mathrm{E}$ - экземпляр целиком; F — крупный план правой плверальной доли торацентрона с зарубцованным краем (белые стрелки) и уменьшенными подвижными шипами.

An adult male specimen with two prosomal abnormalities (Fig. 11E, F). A small 'U'-shaped indentation is noted on the left genal spine lateral border and a ' $\mathrm{V}$ 'shaped indentation is noted on the left genal spine posterior margin. This indentation also shows a hypertrophied the genal spine point.

An adult male with a highly malformed thoracetron (Fig. 12A, B). The anterior section of the right thoracetronic pleural lobe lacks spines and is cicatrised. Only one movable and fixed spine is noted on the posterior section of the right pleural lobe; both are reduced. A 'W'-shaped indentation and an irregular hole in the exoskeleton are noted on the posterior right pleural lobe margin.

An adult male with an abnormal right genal spine (Fig. 12C, D). The genal spine point is rounded when compared to the left side. Furthermore, an additional projection is noted along the posterior margin of the right genal spine.

A large juvenile with an abnormal thoracetron (Fig. 13A). The left thoracetronic pleural lobe has a 'W'shaped indentation that is slightly cicatrised. There are no moveable and fixed spines along the injury margin. 

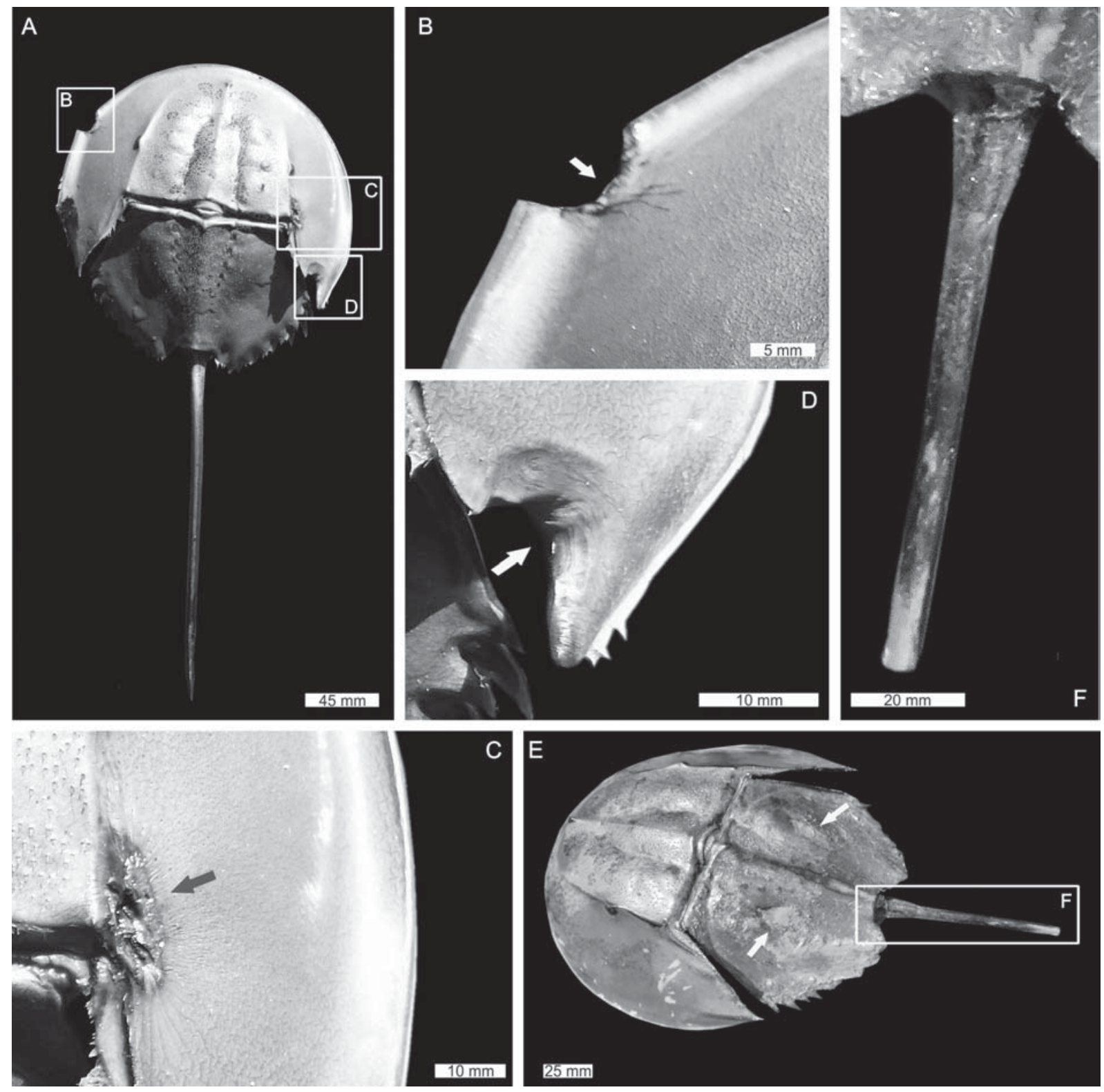

Fig. 8. Carcinoscorpius rotundicauda with prosomal and telson abnormalities. A-D - adult male from the Patiboni region showing three prosomal abnormalities: A - complete specimen; B - close-up of U'-shaped indentation (white arrow) on left side of prosomal shield; C - close-up of hole close to prosomal-thoracetron hinge (grey arrow); D — close-up of ' $U$ '-shaped indentation on the posterior margin of right genal spine (white arrow). E, F - adult female from the Bankimnagar region with butterfly spawning scars and telson abnormality: E - complete specimen showing spawning scars (white arrows); $\mathrm{F}$ - close-up of broken telson. Images converted to greyscale.

Рис. 8. Carcinoscorpius rotundicauda c аномалиями просомы и тельсона. A-D - взрослый самец из района Патибони с тремя аномалиями просомы: А - экземпляр целиком; В - крупный план U'-образного вдавления (белая стрелка) на левом крае щита просомы; C - крупный план углубления близко к сочленению просомы и торацетрона (серая стрелка); D — крупный план 'U'образного вдавления на заднем крае правого щёчного угла (белая стрелка). Е, F - взрослая самка из района Банкимнагар с бабочковидными нерестовыми рубцами и аномалией тельсона: Е - экземпляр целиком с нерестовыми рубцами (белые стрелки); $\mathrm{F}$ - крупный план обломанного тельсона. Иллюстрации преобразованы из цветных в градации серого.

A juvenile with a malformed prosoma and telson (Fig. 13B). The prosoma has at least two small ' $\mathrm{V}$ 'shaped indentations on the anterior border and a large ' $\mathrm{V}$ '-shaped indentation on the right genal spine. The most posterior telsonic section has a slight kink to the right of the specimen's long axis.

A juvenile with a malformed telson (Fig. 13C). The telson is stunted, with a rounded terminus and is curved to the left of the specimens' long axis.

A juvenile with a malformed telson (Fig. 13D, E). The telson is kinked to the right of the long axis.

An adult male with a deformed genal spine and thoracetron (Fig. 14A-C). The right genal spine has a rounded edge and is approximately half the length of 

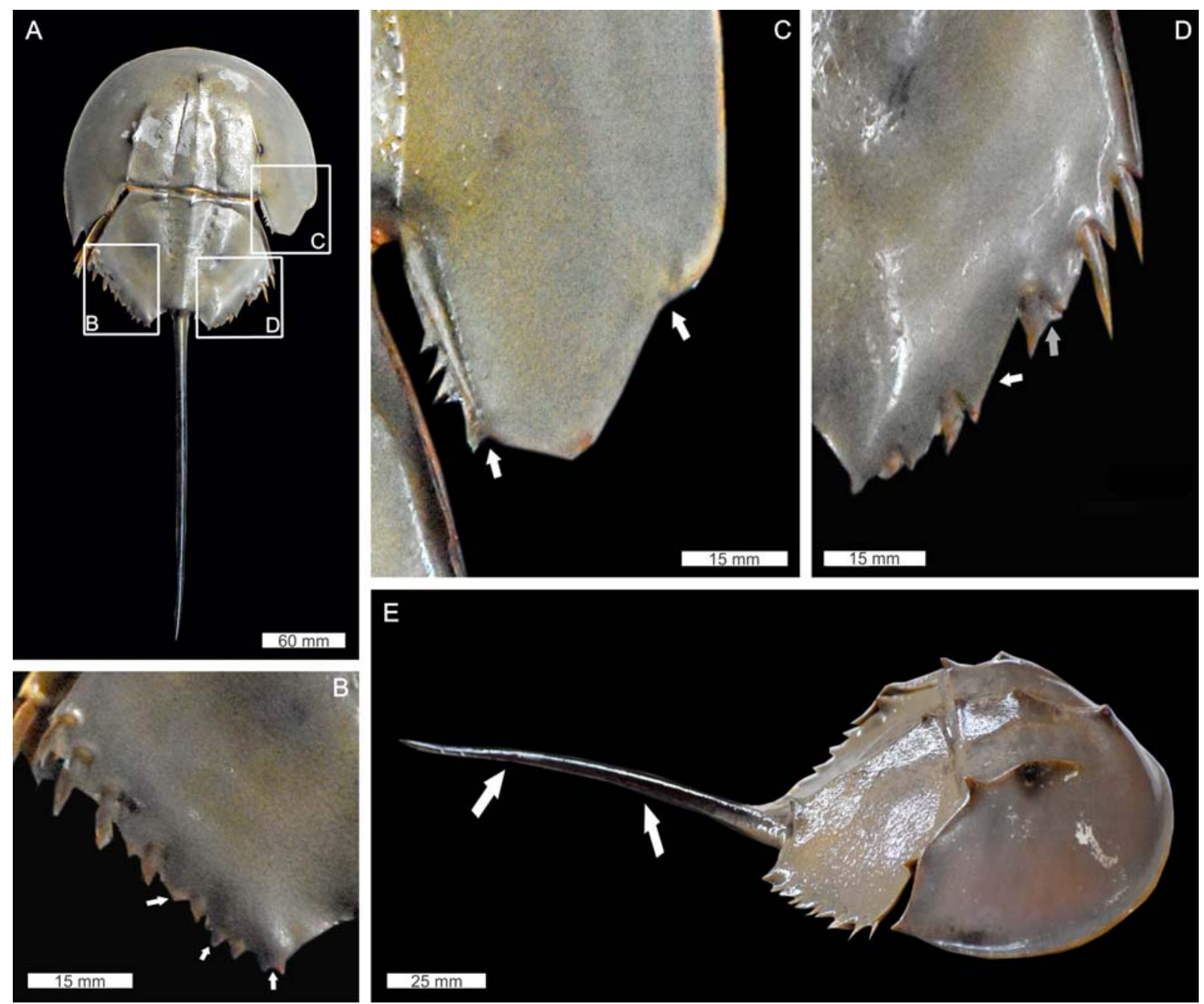

$25 \mathrm{~mm}$

Fig. 9. Carcinoscorpius rotundicauda with prosomal, thoracetronic, and telson abnormalities. A-D - an adult female from Patiboni region with a malformed genal spine and thoracetronic abnormalities: A - complete specimen; B - close-up of left thoracetronic pleural lobe having stunted fixed and moveable spines (white arrows); $\mathrm{C}$ - close-up of truncated and rounded right genal spine with ' $U$ '- and ' $\mathrm{V}$ 'shaped indentations (white arrows); D — close-up of right thoracetronic pleural lobe showing stunted fixed and moveable spines (white arrow) and the overlap between the second and third fixed spines (grey arrow). E - juvenile from Patiboni region with malformed telson (white arrows).

Рис. 9. Carcinoscorpius rotundicauda с аномалиями просомы, торацетрона и тельсона. A-D - взрослая самка из района Патибони с видоизмененным щёчным углом и аномалиями торацентрона: А - экземпляр целиком; В - крупный план левой плевральной доли торацентрона с недоразвитыми фиксированными и подвижными шипами (белые стрелки); С - крупный план усеченного и закругленного щёчного угла с 'U'- и 'V'-образными вдавлениями (белые стрелки); D - крупный план правой плевральной доли торацентрона с недоразвитыми фиксированными и подвижными шипами (белая стрелка) и разрастанием между вторым и третьим фиксированными шипами (серая стрелка). Е — ювениль из района Патибони с видоизмененным тельсоном (белые стрелки).

the left genal spine. The left thoracetronic pleural lobe has two movable spines in the anterior-most spine notch. The posterior-most fixed and movable spines are absent and the terminal thoracetronic spine is blunt.

A juvenile with a malformed telson (Fig. 14D, E). The telson is approximately $50 \%$ the length of a noninjured individual and has a broken terminus.

An adult female with a malformed thoracetron and telson (Fig. 15A, B). The anterior-most movable spine on the right thoracetronic pleural lobe is $\sim 50 \%$ smaller than the corresponding spine on the left side. The two posterior-most movable and fixed spines on the right thoracetronic pleural lobe are apparently absent. A 'W'shaped abnormality is noted on the left thoracetronic pleural lobe and the posterior most movable spines on the right thoracetronic pleural lobe are absent and lack associated spine notches. Finally, the telson is short and has a blunt terminus.

An adult female with malformations on the prosoma, thoracetron and telson (Fig. 15C-F). A depression is noted on the ventral prosomal surface, anterior to the mesial spine. The left thoracetronic pleural lobe has at least two ' $\mathrm{V}$ '-shaped indentations and two ' $\mathrm{W}$ '-shaped 

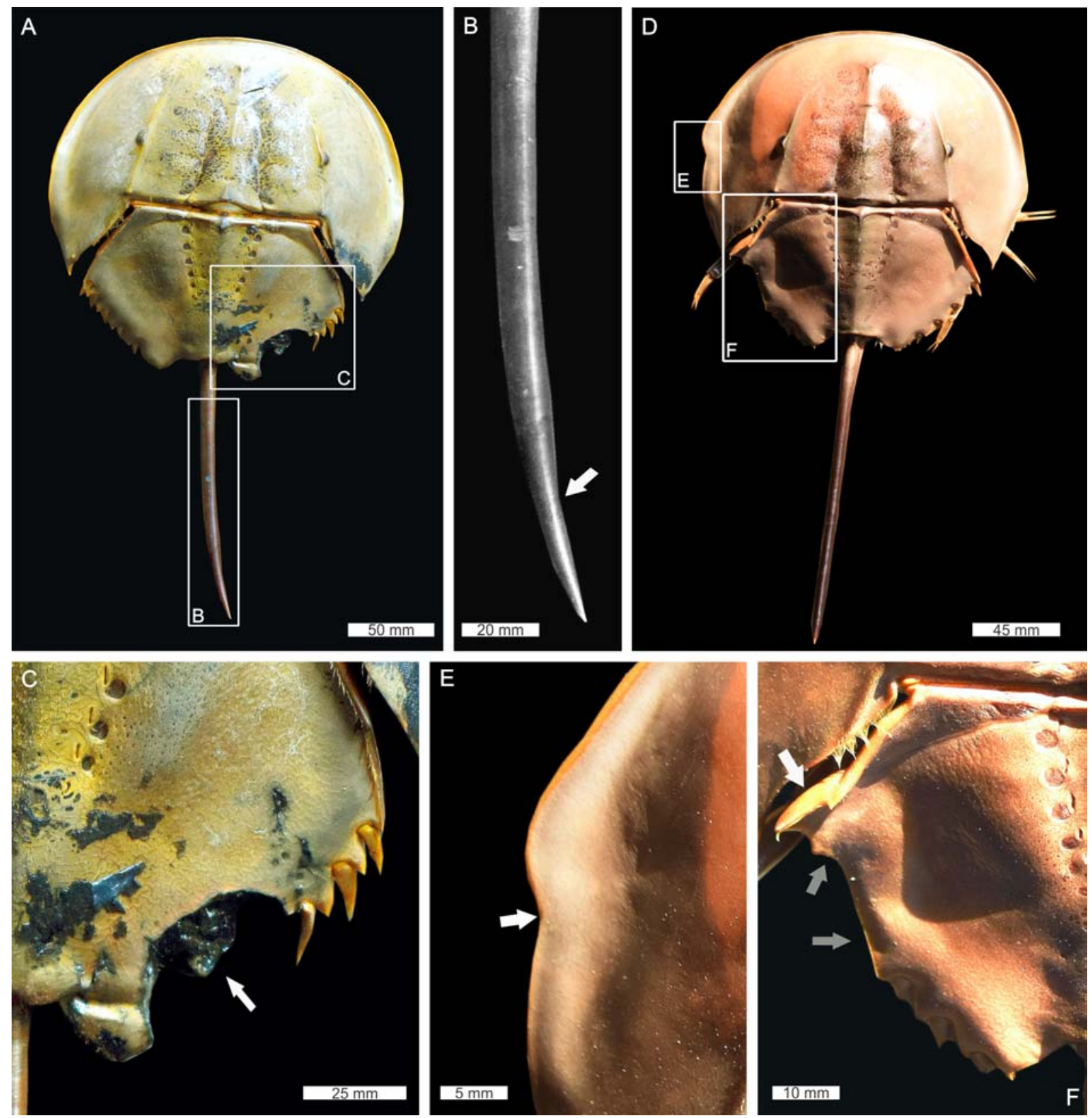

Fig. 10. Carcinoscorpius rotundicauda with prosomal, thoracetronic, and telson abnormalities. A-C - adult male from Patiboni region with abnormal right thoracetron and telson: A - complete specimen; B - close-up of telson showing decrease of telson width at the distal section (white arrow); C - close-up of right thoracetronic pleural lobe with large ' $U$ '-shaped indentation (white arrow). D-F adult male from the Patiboni region with abnormal prosoma and left thoracetronic side: D - complete specimen; E — close-up of left prosoma with ' $\mathrm{V}$ '-shaped indentation (white arrow); F - close-up of abnormalities on the thoracetron. The posteriorly folded free lobe (white arrow) and the anterior thoracetronic border lacking fixed and moveable spines (grey arrows)

Рис. 10. Carcinoscorpius rotundicauda с аномалиями просомы, торацетрона и тельсона. А-C — взрослый самец из района Патибони с аномалиями правой части торацентрона и тельсона: А - экземпляр целиком; В - крупный план тельсона, показано уменьшение ширины тельсона в его дистальной части (белая стрелка); С — крупный план оf правой плевральной доли торацентрона c 'U'-образным вдавлением (белая стрелка). D-F — взрослый самец из района Патибони с аномальной просомой и левой стороной торацентрона: D - экземпляр целиком; E — крупный план левой стороны просомы с 'V'-образным вдавлением (белая стрелка); F крупный план аномалий торацентрона. Сложенная сзади свободная доля (белая стрелка) и передняя граница торацентрона с отсутствующими фиксированными и подвижными шипами (серые стрелки).

indentations. The pleural lobe is half the length of the right pleural lobe. Only the three anterior-most movable spines are noted and these are stunted. Two spines are orientated laterally, as opposed to being posterolat- erally. The posterior-most movable and fixed spines are absent. The right thoracetronic pleural lobe has stunted moveable and fixed spines in the posteriormost section. The terminal thoracetronic spine is curved 

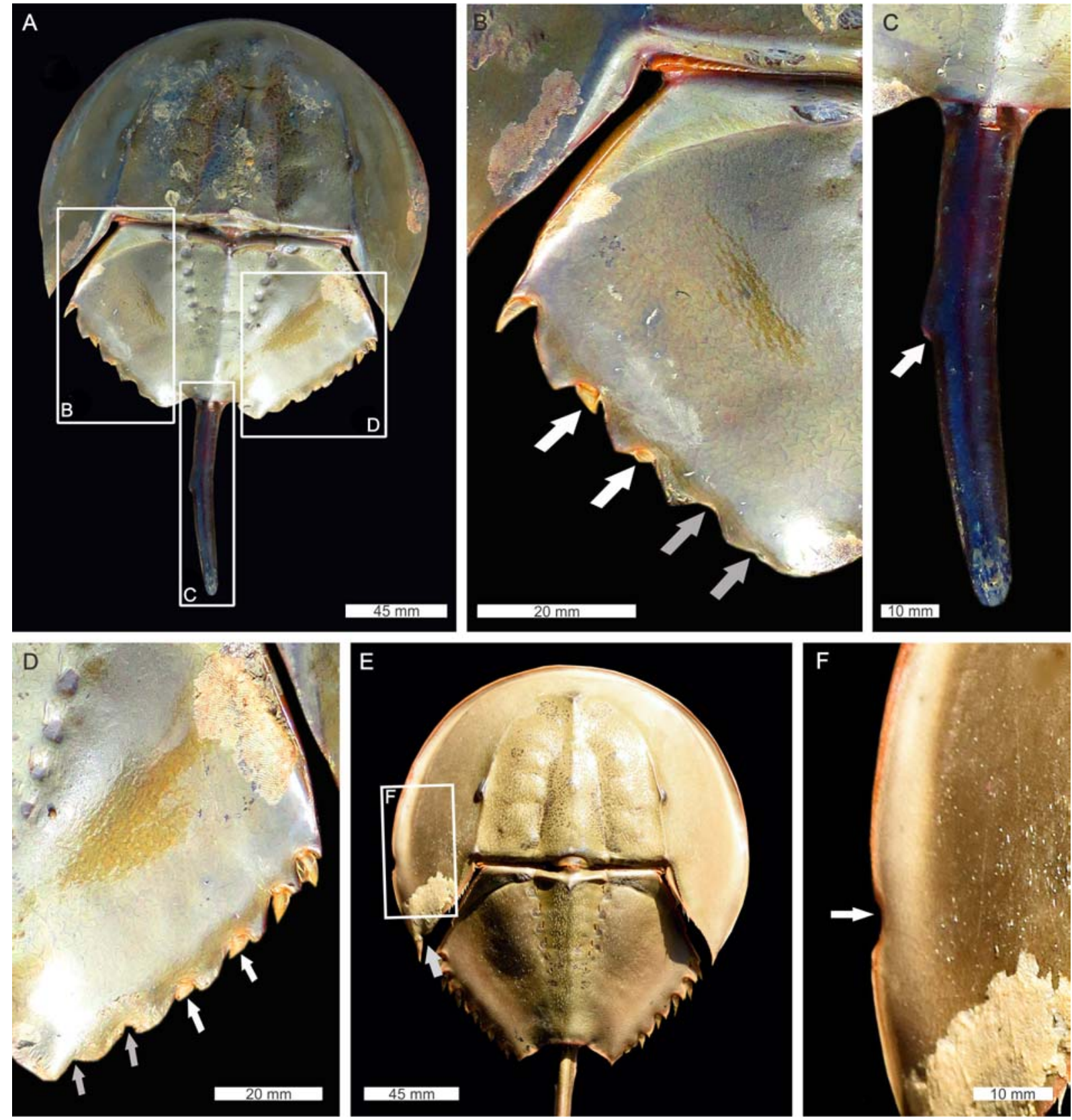

Fig. 11. Carcinoscorpius rotundicauda with prosomal, thoracetronic, and telson abnormalities. A-D - adult male from the Bankimnagar region with malformed thoracetron and telson: A - complete specimen; B - close-up of left thoracetronic pleural lobe showing stunted (white arrows) and missing moveable spines (grey spines); C — close-up of telson with small projection half way along spine (white arrow); D - close-up of right thoracetronic pleural lobe showing stunted (white arrows) and missing moveable spines (grey arrows). E, F — adult male from the Patiboni region with abnormal prosoma: $\mathrm{E}$ - complete specimen showing ' $\mathrm{V}$ '-shaped indentation on posterior margin of left genal spine (grey arrow); F — close-up of left genal spine showing 'U'-shaped indentation (white arrow).

Рис. 11. Carcinoscorpius rotundicauda с аномалиями просомы, торацетрона и тельсона. A-D - взрослый самец из района Банкимнагар с видоизмененными торацентроном и тельсоном: А - экземпляр целиком; В - крупный план левой плевральной доли торацентрона с недоразвитыми (белые стрелки) и отсутствующими подвижными шипами (серые стрелки); С - крупный план тельсона с небольшим выступом на середине иглы (белая стрелка); D - крупный план правой плверальной доли торацентрона с недоразвитыми (белые стрелки) и отсутствующими подвижными шипами (серые стрелки). E, F — взрослый самец из района Патибони с аномальной просомой: Е — экземпляр целиком с 'V'-образным вдавлением на заднем крае левого щёчного угла (серая стрелка); F — крупный план левого щёчного угла с 'U’-образным вдавлением (белая стрелка).

towards the sagittal axis. The telson is kinked to the right within the last quarter of the spine length.

A juvenile with a malformed thoracetron and telson (Fig. 16A-D). The left thoracetronic pleural lobe has three moveable spines and four moveable spine notches. The right thoracetronic pleural lobe is missing the anterior-most movable. The telson is kinked at two points and has a slightly rounded terminus. 

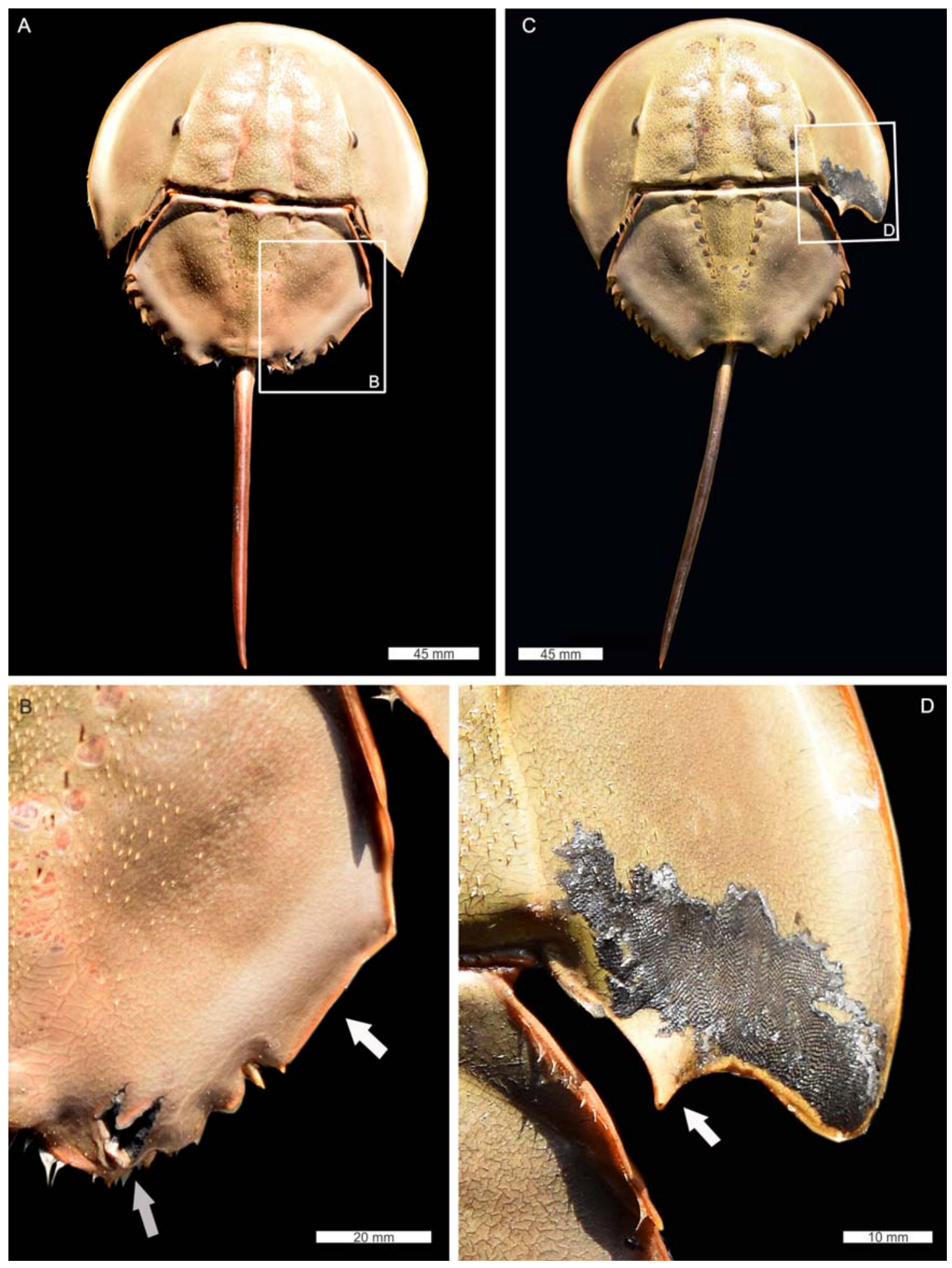

Fig. 12. Carcinoscorpius rotundicauda with prosomal and thoracetronic abnormalities. A, B - adult male from the Patiboni region with abnormal right thoracetron: A - complete specimen; B - close-up of malformed thoracetron showing cicatrised region lacking movable spines (white arrow) and a W'-shaped indentation next to hole in exoskeleton (grey arrow). C, D - adult male from the Patiboni region with abnormal right genal spine: $\mathrm{C}$ - complete specimen; D - close-up of rounded genal spine showing posteriorly directed projection (white arrow).

Рис. 12. Carcinoscorpius rotundicauda с аномалиями просомы и торацетрона. А, В - взрослый самец из района Патибони с аномалиями правой части торацентрона: А - экземпляр целиком; В - крупный план видоизмененного торацентрона с зарубцованной областью с отсутствующими подвижными шипами (белая стрелка) и W'-образным вдавлением рядом с углублением в экзоскелете (серая стрелка). C, D - взрослый самец из района Патибони с аномальным правым щёчным углом: С экземпляр целиком; D - крупный план закругленного щёчного угла с направленными назад выступом (белая стрелка). 

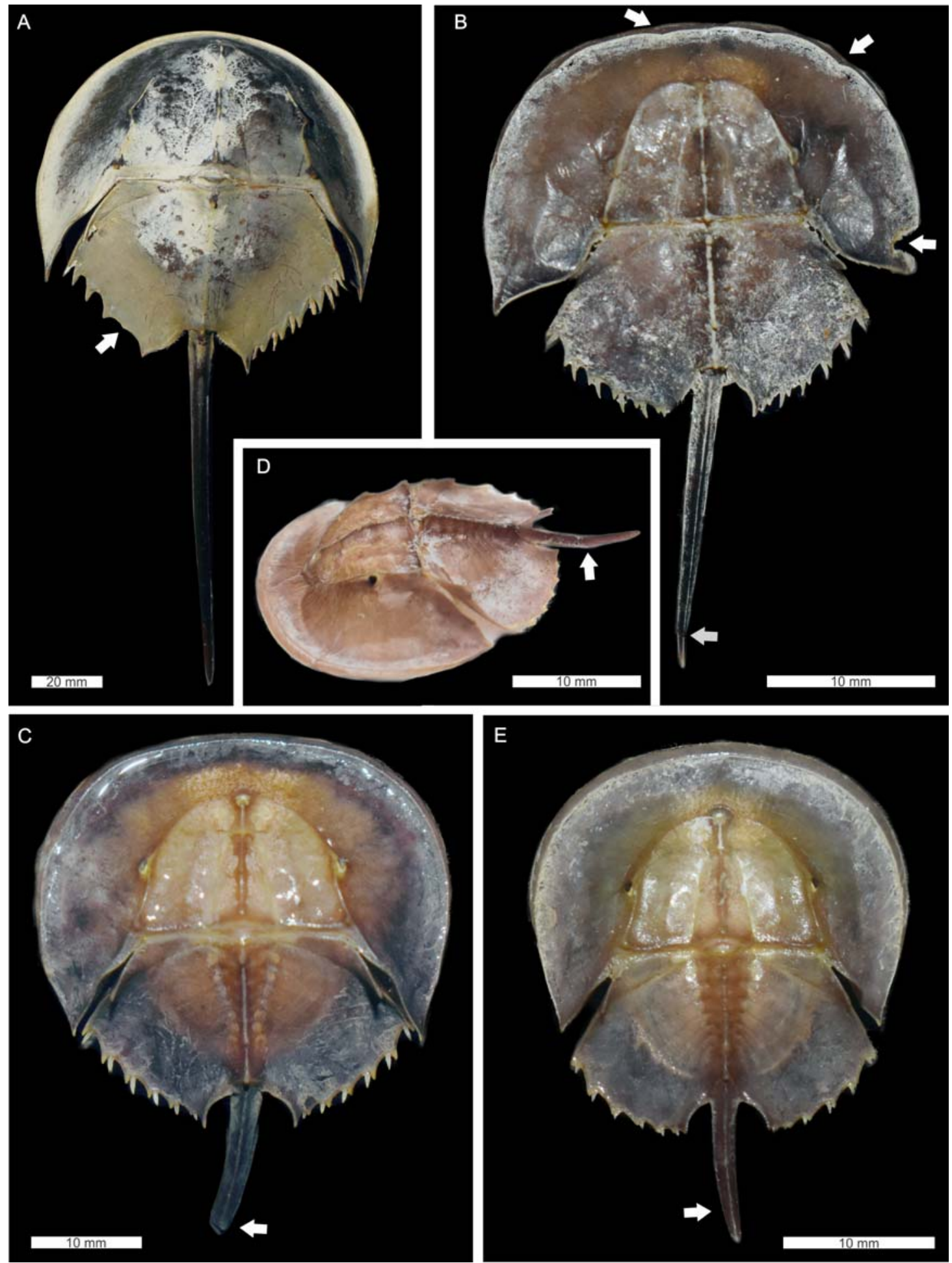

Fig. 13. Carcinoscorpius rotundicauda juveniles showing prosomal, thoracetronic and telson abnormalities. A - specimen from the Beguakhali region with a 'W'-shaped indentation on left thoracetronic pleural lobe (white arrow). B - specimen from the Patiboni region with 'V'-shaped indentations on prosoma (white arrows) and a kinked telson (grey arrow). C - specimen from the Patiboni region with a stunted and curved telson (white arrow). D, E — specimen from Jharkhali region with a malformed telson (white arrows), in lateral (D) and dorsal (E) views.

Рис. 13. Ювенили Carcinoscorpius rotundicauda с аномалиями просомы, торацетрона и тельсона. А — экземпляр из района Бегуакхали c 'W'-образным вдавлением на левой плевральной доле торацентрона (белая стрелка). В - экземпляр из района Патибони c 'V'-образными вдавлениями на просоме (белые стрелки) и перекрученным тельсоном (серая стрелка). C — экземпляр из района Патибони с недоразвитым и изогнутым тельсоном (белая стрелка). D, E - экземпляр из района Джхаркхали с видоизмененным тельсоном (белые стрелки), латерально (D) и дорсально (Е). 

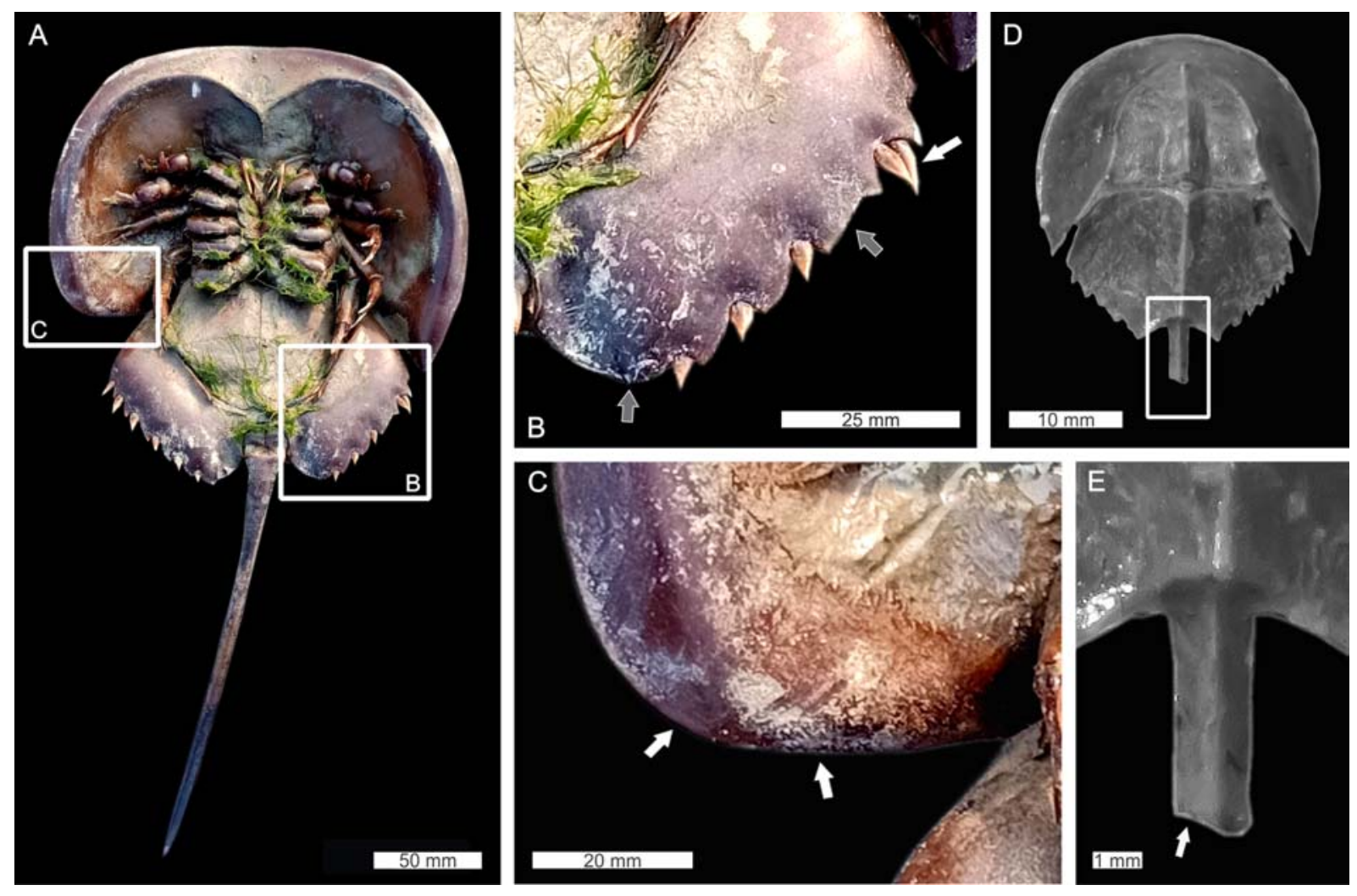

Fig. 14. Carcinoscorpius rotundicauda with prosomal, thoracetronic and telson abnormalities. A-C - adult male from the Patiboni region showing deformed genal spine and thoracetron in ventral view: A - complete specimen; B — close-up of left thoracetronic pleural lobe with two moveable spines at the same notch (white arrow) and missing spines and spine notches (grey arrows); C — close-up of right genal spine with rounded edge (white arrows). D, E - juvenile specimen from the Patiboni region with malformed telson: D - complete specimen; E - close-up of broken telson (white arrow). D and E are converted to grayscale.

Рис. 14. Carcinoscorpius rotundicauda с аномалиями просомы, торацетрона и тельсона. А-C - взрослый самец из района Патибони с деформированными щёчным углом и торацентроном, вентрально: А 一 экземпляр целиком; В — крупный план левой превральной доли торацентрона с двумя подвижными шипами в одной выемке (белая стрелка) и отсутствующими шипами и их выемками (серые стрелки); С — крупный план правого щёчного угла с закругленным краем (белые стрелки). D, Е — ювенильный экземпляр из района Патибони с видоизмененным тельсоном: D — экземпляр целиком; Е — крупный план обломанного тельсона (белая стрелка). Рисунки D и Е преобразованы в градации серого.

An adult male with a deformed thoracetron (Fig. $16 \mathrm{E}, \mathrm{F})$. The left thoracetronic pleural lobe has a cicatrised edge and a 'W'-shaped indentation along the posterior margin. Furthermore, only one small movable spine and spine notch are noted.

An adult male with malformed appendages (Fig. 17). The distal sections of the first left leg are missing and the damaged section is cicatrised. The distal region of the coxal section on the left pushing leg has a hole. Finally, the posterior sections of the genital opercular have 'U'-shaped indentations on both sides.

Both malformed and normal specimens fall into similar spaces for the prosomal and thoracetronic datasets when considering the distribution of specimens in log-normalised bivariate space (Fig. 18). The malformed specimens have a slightly courser frequency distribution, likely reflecting the smaller counts, relative to normal individuals. Specimens with a slightly wider than long prosoma are more likely to show some form of abnormality (Fig. 18A). Thoracetronic measurements show that those individuals with a smaller thoracetron are likely to show an abnormality (Fig. 18B). Overall, these data also show clear clusters in bivariate space, suggesting a possible record of ontogenetic change.

Anthropogenic pressures that negatively impact xiphosurids were observed during the study. We noted that telsons are often gathered and used as amulets. Furthermore, a subset of the local people consume Carcinoscorpius rotundicauda as a food source. Beyond these uses, iron rods, fish nets, boats in the Patiboni, Bankimnagar, and Mayagoalinir Ghat regions interact and impact the local $C$. rotundicauda populations. Grazing livestock were observed in association with horseshoe crab populations, an interaction that may also impact the xiphosurids as well. Finally, the mangroves are often harvested for fuel, so habitat modification will have influenced the species. 

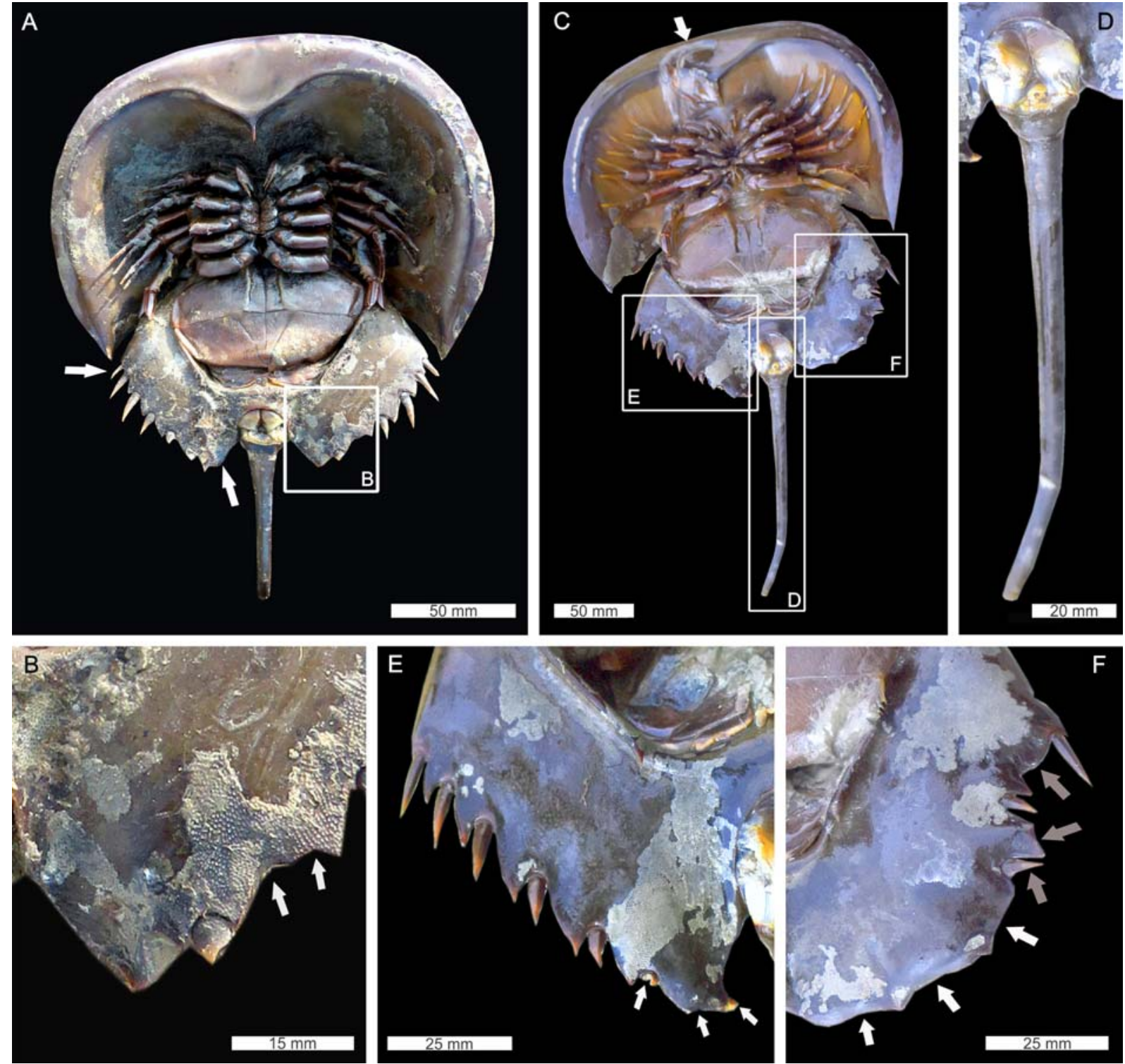

Fig. 15. Carcinoscorpius rotundicauda with thoracetronic and telson abnormalities. A, B - adult female from the Bankimnagar region with malformed thoracetron and telson in ventral view: A - complete specimen showing deformed moveable spines on right thoracetronic pleural lobe (white arrows) and broken telson; B - close-up of left thoracetronic pleural lobe showing 'W'-shaped abnormality (white arrows). C-F - adult male from the Kostola region with thoracetronic and telson abnormalities in ventral view: C complete specimen showing circular depression in prosoma (white arrow); D — close-up of right-kinked telson; E — close-up of stunted moveable spines on right thoracetronic pleural lobe (white arrows); F — close-up of 'V'-shaped (grey arrows) and 'W'-shaped (white arrows) indentations on right thoracetronic pleural lobe.

Рис. 15. Carcinoscorpius rotundicauda с аномалиями торацетрона и тельсона. А, В - взрослая самка из района Банкимнагар с видоизмененными торацентроном и тельсоном, вентрально: А - экземпляр целиком с деформированными подвижными шипами на правой плевральной доле торацентрона (белые стрелки) и обломанным тельсоном; В - крупный план левой плевральной доли торацентрона c 'W'-образной аномалией (белые стрелки). C-F - взрослый самец из района Костола с аномалиями торацентрона и тельсона, вентрально: C - экземпляр целиком с круговым вдавлением на просоме (белая стрелка); D — крупный план закрученного направо тельсона; E — крупный план недоразвитых подвижных шипов на правой плевральной доле торацентрона (белые стрелки); F - крупный план 'V'-образных (серые стрелки) и 'W'-образных (белые стрелки) вдавлений на правой плевральной доле торацентрона.

\section{Discussion}

Comparing the documented abnormalities to other malformed horseshoe crabs [Shuster Jr., 1982; Bicknell et al., 2018; Bicknell, Pates, 2019] and to trilo- bites - organisms with a morphologically comparable body plan [Owen, 1985; Babcock, 1993; Bicknell et al., 2019d; Bicknell, Pates, 2020] — we conclude that the majority of abnormalities documented here represent injuries. The ' $V$ '-, ' $U$ '- and ' $W$ '-shaped indentations on prosomal and thoracetronic sections likely 

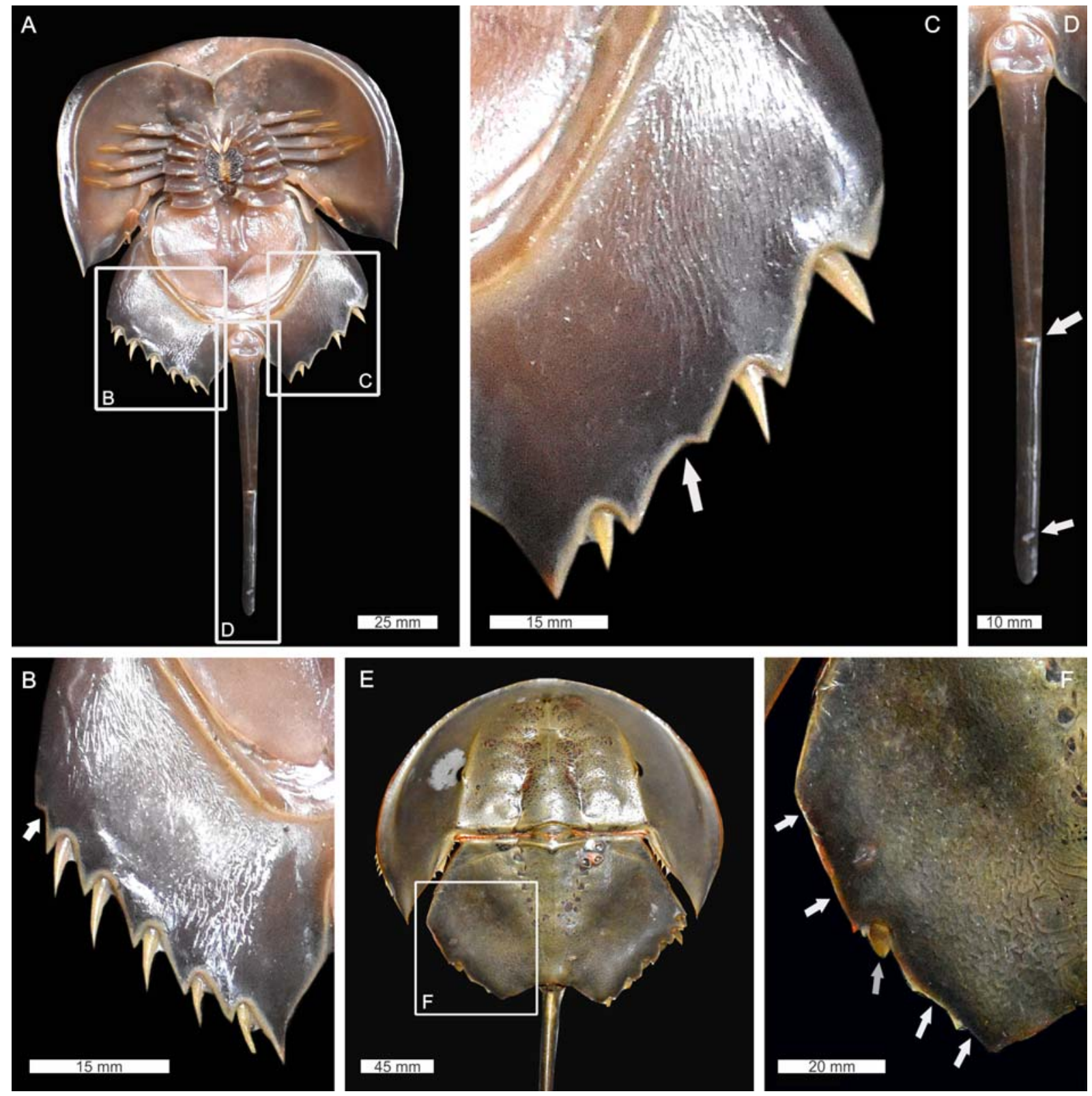

Fig. 16. Carcinoscorpius rotundicauda with thoracetronic and telson abnormalities. A-D - juvenile specimen from the Patiboni region with malformed thoracetron and telson in ventral view: A - complete specimen; B - close-up of right thoracetronic pleural lobe showing missing moveable spine (white arrow); $\mathrm{C}$ - close-up of left thoracetronic pleural lobe showing missing moveable spines (white arrow); D - close-up of telson abnormality showing kinked areas (white arrows). E, F - adult male from the Patiboni region with thoracetronic abnormality: E - complete specimen; F — close-up of the deformed left thoracetronic pleural lobe showing missing moveable spines (white arrows) and a stunted moveable spine (grey arrow).

Рис. 16. Carcinoscorpius rotundicauda с аномалиями торацетрона и тельсона. A-D - ювенильный экземпляр из района Патибони с видоизмененными торацентроном и тельсоном, вентрально: А - экземпляр целиком; В — крупный план правой плевральной доли торацентрона с отсутствующим подвижным шипом (белая стрелка); C - крупный план левой плевральной доли торацентрона с отсутствуюшими подвижными шипами (белая стрелка); D - крупный план аномалий тельсона с областями скручивания (белые стрелки). Е, F — взрослый самец из района Патибони с аномалией торацентрона: $\mathrm{E}$ - экземпляр целиком; $\mathrm{F}$ - крупный план деформированной левой плевральной доли торацентрона с отсутствующими подвижными шипами (белые стрелки) и уменьшенным подвижным шипом (серая стрелка).

record mechanical damage to the exoskeleton. The shallower ' $U$ '- and ' $V$ '-shaped injuries record possible tearing of softer exoskeleton after moulting and/or an injury that has recovered during more recent moulting events [Pates, Bicknell, 2019]. Further, those specimens show- ing cicatrisation represent definite evidence of recovery from the injury event.

The causes of these injuries should be considered. The most extreme records of damage (e.g. Figs 5A, B; $9 \mathrm{~A} ; 15 \mathrm{C}, \mathrm{F})$ may reflect interactions with boats and 


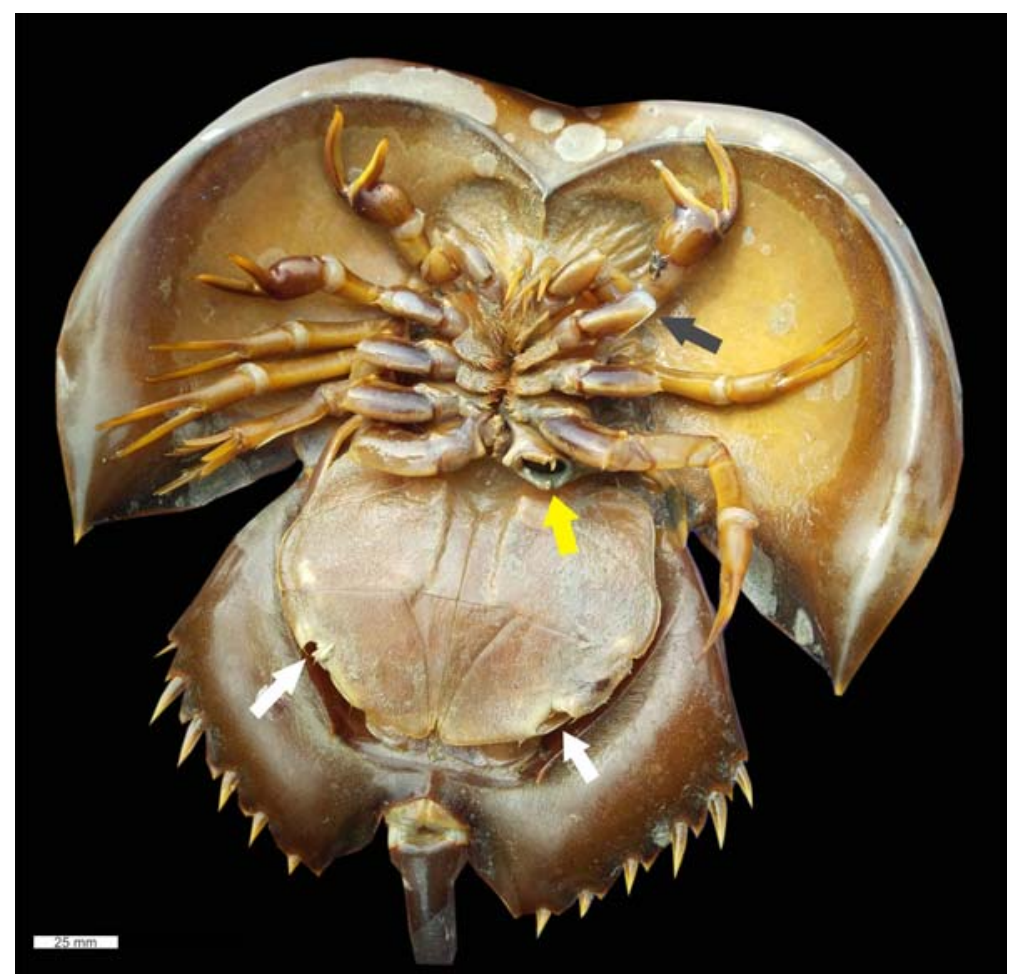

Fig. 17. Adult male Carcinoscorpius rotundicauda from the Patiboni region with malformed appendages. The first male leg on the left side is stunted (grey arrow), the coxal section of the left pushing leg is damaged (yellow arrow) and there are ' $U$ '-shaped indentations are noted on both sides of the genital opercula (white arrows).

Рис. 17. Взрослый самец Carcinoscorpius rotundicauda из района Патибони с видоизмененными придатками. Первая левая нога уменьшена (серая стрелка), коксальная часть левой толкательной ноги повреждена (желтая стрелка) и имеются 'U'-образные вдавления на обеих сторнах генитальной крышечки (белые стрелки).

livestock that now co-occur with horseshoe crabs. Select injuries could be considered bite marks (Figs 7B, $10 \mathrm{~A}$ ) and they are likely record of predator-prey interactions. The local people suggest rats are possible culprits for such injuries. As turtles and gulls are known to cause injuries to Limulus polyphemus [Keinath, 2003; Bicknell et al., 2018], similar predators may also have contributed to the records observed here.

There is an array of morphologies that reflect abnormal recovery from injuries. The rounded genal spines (Figs 4A, 9A, 12C, 14A) undoubtedly reflect regeneration from an injury, but a lack of sufficient moulting events to completely recover the spine. The condition where two moveable spines are noted within the same thoracetronic spine notch (Figs 4B, 12B) likely reflects a developmental malfunction during recovery of an injury to the thoracetronic margin. An unequal number of moveable and fixed spines indicates an injury that resulted in the removal of a spine and this removal has not completely recovered (Figs 3D, 11A, 15A, 16A). Finally, stunted, kinked or absent telson spines (Figs 7B, D, 9B, D, 10D, 13B, E, F, 14F) likely reflect deformation of the spine through mechanical damage and the propagation of the malformation during subsequent moults [Bicknell et al., 2018].

Previous studies of horseshoe crab abnormalities [Shuster Jr., 1982; Botton, Loveland, 1989; Bicknell et al., 2018] suggested that telson abnormalities were the most documented examples of horseshoe crab malformations. However, the studied Carcinoscorpius rotundicauda populations illustrate that prosomal and thoracetronic injuries are most abundant. This suggests that, as Bicknell \& Pates [2019] postulated, there may be species-specific patterns of injuries. Alternatively, the prevalence of injury locations is dictated by the ecological conditions imposed on a given population. Regardless, further research into injury patterns is needed; specifically using living populations. Such studies will likely identify those populations with abundant injuries and ideally help inform conservation efforts that are direly needed to prevent the extinction of these iconic organisms.

Acknowledgements. This research is part of the doctoral thesis of Swati Das. Our sincere thanks to the Director of the Zoological Survey of India for providing all necessary permission to carry out the field work and fellowship to Swati Das. We are grateful to all field staff at the Forest Department for logistics. Russell Dean Christopher Bicknell is funded by a University of New England Postdoctoral Fellowship. Finally, we thank Serge Naugolnykh for his review that improved the flow and use of the text.

Author contributions. S.D. collected data, wrote the first version of the text. B.T. conceived the initial idea and 
A

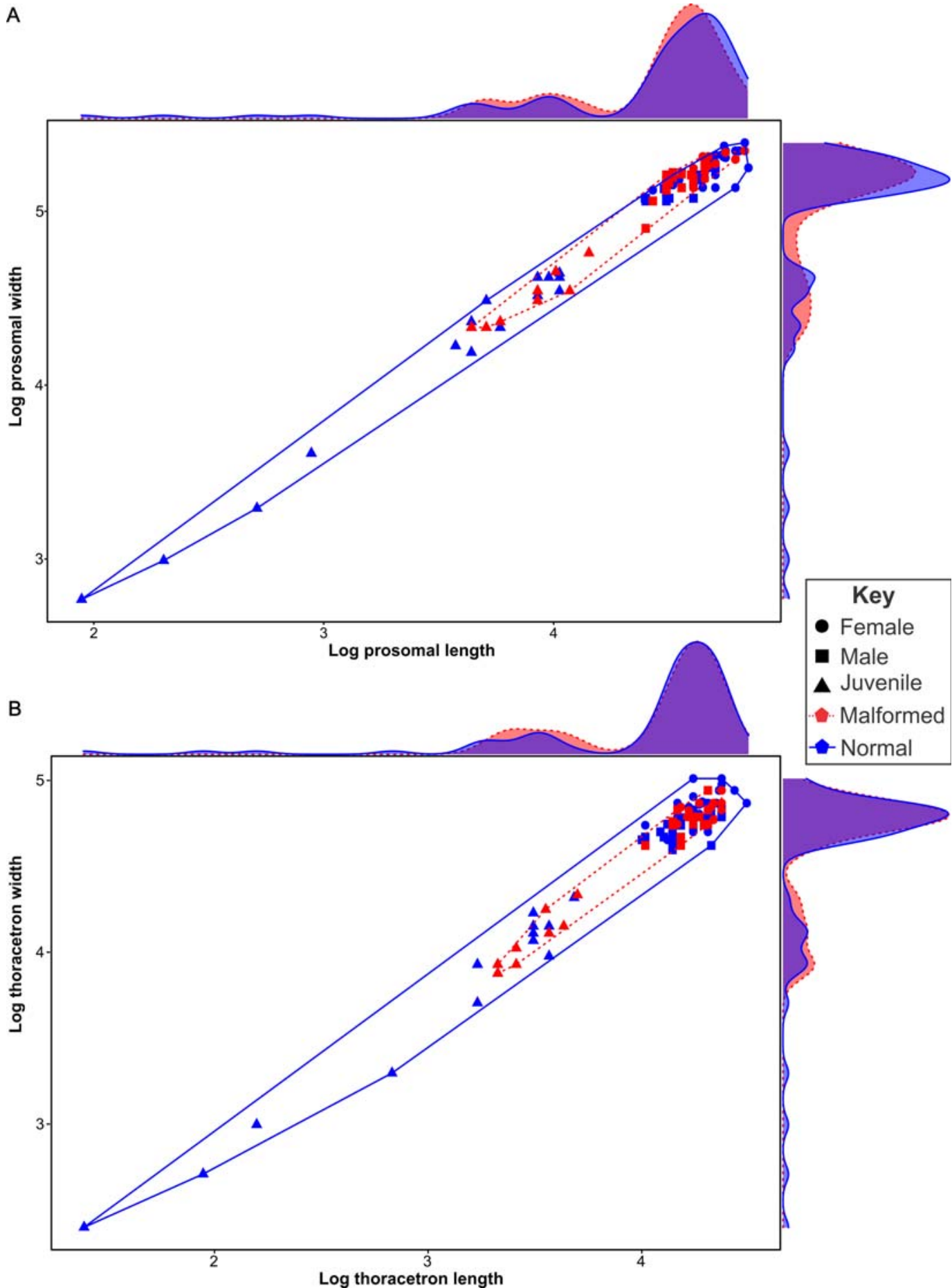

Fig. 18. Bivariate plots sampled horseshoe crabs coded for gender and the presence of absence of an abnormality. A - plot of lognormalised prosomal measurements with groups bound by convex hulls. Malformed specimens generally fall within the convex hull of normal specimens. Both groups have a similar frequency plot, with abnormal specimens peaking more along the prosomal length axis; B plot of log-normalised thoracetronic measurements with groups bound by convex hulls. Malformed specimens fall within the convex hull of normal specimens. Both groups have a similar frequency plot, although the malformed specimens have a lower resolution distribution, reflecting the limited population relative to normal specimens. The data associated with these plots are found in Supplemental Data 1.

Рис. 18. Двумерные графики собранных мечехвостов с указанием пола и наличия/отсутствия аномалий. A — график logнормальных промеров просомы, с областями значения. Видоизмененные образцы обычно попадают в области значения нормальных образцов. Обе группы имеют сходный график частот, с аномальными экземплярами, дающими больший пик вдоль оси длины просомы; В - график $\log$-нормальных промеров торацентрона, с областями значения. Экземпляры с отклонениями попадают в область значений нормальных экземляров. Обе группы имеют сходный график частот, хотя видоизмененные экземпляры имеют более низкое распределение, что отражает меньшее их количество по сравнению с нормальными экземплярами. Данные по этим графикам даны в Supplemental Data 1. 

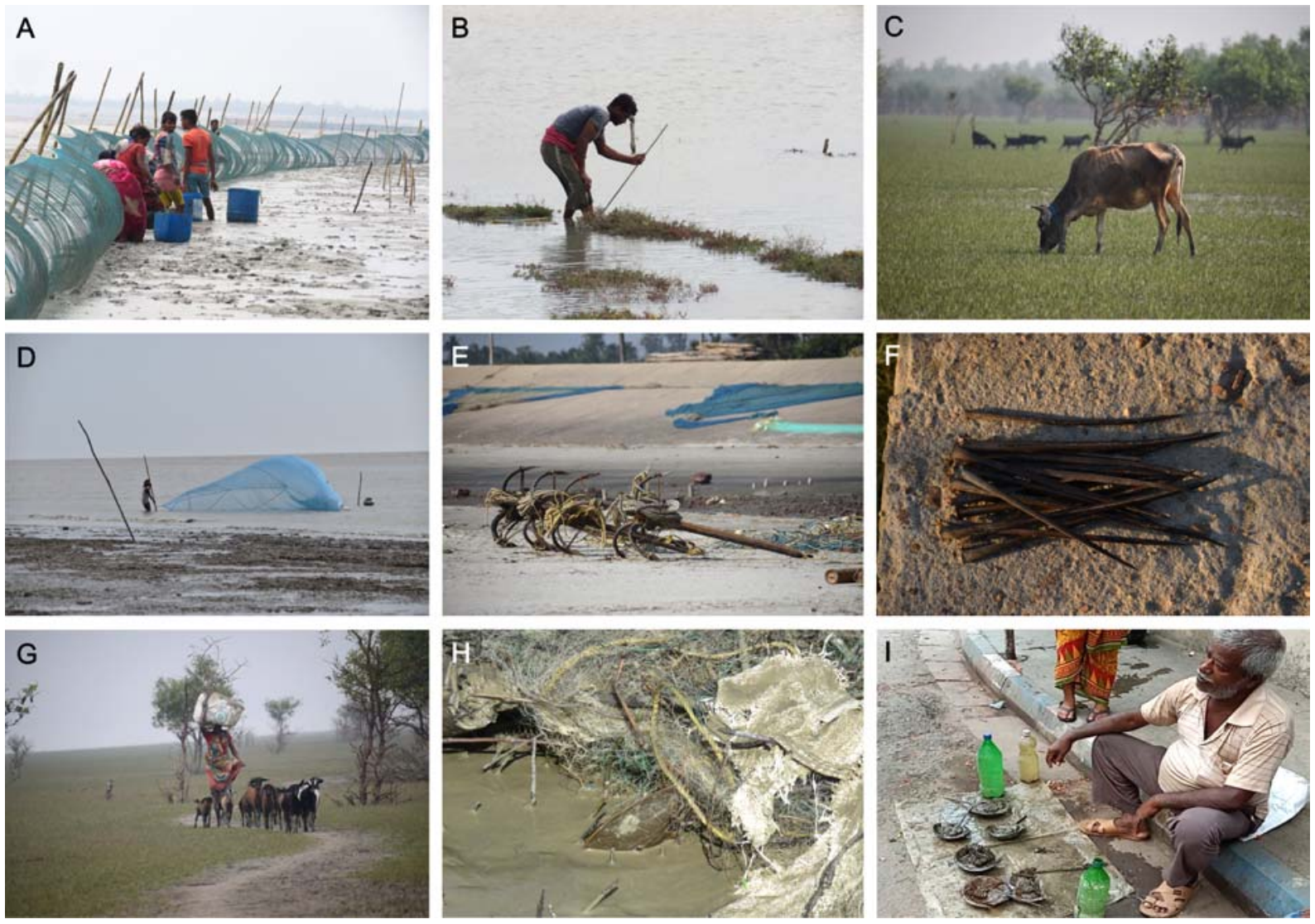

Fig. 19. Illustrations of anthropogenic activities that negatively impact horseshoe crabs at the study sites. A, D — fishing nets (Bet jals) at the intertidal zone to collect small and medium sized fish during low tide; B - the collection of decapod crustaceans in mud-flats using iron rods; $\mathrm{C}$ - livestock grazing on the mudflats; E - anchors located on the mudflats; F — Carcinoscorpius rotundicauda telson spines that are broken and collected by local people; $\mathrm{G}$ - destruction of mangrove trees for fuel and food; $\mathrm{H}$ - a horseshoe crab entangled in abandoned fish net; I - trade of horseshoe crabs at a local market of Kolkata, West Bengal.

Рис. 19. Примеры антропогенной активности, негативно влияющей на мечехвостов в изученных местах. A, D - рыболовные сети (Bet jals) в приливно-отливной зоне, предназначенные для сбора мелкой и среднеразмерной рыбы во время отлива; В - сбор десятиногих ракообразных на грязевых отмелях при помощи палки с металлическим шипом; С - скот пасущийся на грязевых отмелях; Е - якори, размещенные на грязевых отмелях; F — шипы тельсонов Carcinoscorpius rotundicauda, обломанные и собранные местным населением; $\mathrm{G}$ - заготовка деревьев мангров для топлива и пищи; Н - мечехвост, запутавшийся в заброшенной рыболовной сети; I — торговля мечехвостами на местеной рынке в Колкате, Западный Бенгал.

supported the logistics for field work. K.A.S. guided the work of S.D. as part of her doctoral thesis. S.D. and R.D.C.B. designed the study and the figures. R.D.C.B. analysed the measurement data, edited the text, and developed ideas. All authors read and contributed the final draft.

\section{Compliance with ethical standards}

Conflict of Interest: The authors declare that they have no conflict of interest.

Ethical approval: No ethical issues were raised during our research.

\section{Supporting Information}

Additional supporting information can be found online.

Supplemental Data 1. Morphometric and gender data used in Figure 18.

\section{References}

Almendral M.A., Schoppe S. 2005. Population structure of Tachypleus tridentatus (Chelicerata: Merostomata) at a nursery beach in Puerto Princesa City, Palawan, Philippines // Journal of Natural History. Vol.39. No.25. P.2319-2329.

Annandale N. 1909. The habits of Indian king crabs // Record of the Indian Museum. Vol.3. P.294-295.

Babcock L.E. 1993. Trilobite malformations and the fossil record of behavioral asymmetry // Journal of Paleontology. Vol.67. No.2. P.217-229.

Bicknell R.D.C., Pates S. 2019a. Abnormal extant xiphosurids in the Yale Peabody Museum Invertebrate Zoology collection // Bulletin of The Peabody Museum of Natural History. Vol.60. No.1. P.41-53.

Bicknell R.D.C., Brougham T., Charbonnier S., Sautereau F., Hitij T., Campione N.E. 2019b. On the appendicular anatomy of the xiphosurid Tachypleus syriacus and the evolution of fossil horseshoe crab appendages // The Science of Nature. Vol.106. No.7. P.38.

Bicknell R.D.C., Naugolnykh S.V., Brougham T. 2020. A reappraisal of Paleozoic horseshoe crabs from Russia and Ukraine // The Science of Nature. Vol.107. P.46.

Bicknell R.D.C. 2019c. Xiphosurid from the Upper Permian of Tasmania confirms Palaeozoic origin of Austrolimulidae // Palaeontologia Electronica. Vol.22. No.3. P.1-13.

Bicknell R.D.C., Paterson J.R., Hopkins M.J. 2019d. A trilobite cluster from the Silurian Rochester Shale of New York: preda- 
tion patterns and possible defensive behavior // American $\mathrm{Mu}-$ seum Novitates. Vol.39. No.3937. P.1-16.

Bicknell R.D.C., Pates S. 2020a. Pictorial atlas of fossil and extant horseshoe crabs, with focus on Xiphosurida // Frontiers in Earth Science. Vol.8. No.98. P.60.

Bicknell R.D.C., Pates S. 2020b. Exploring abnormal Cambrianaged trilobites in the Smithsonian collection // PeerJ. Vol.8. P.e8453.

Bicknell R.D.C., Holland B. 2020. Injured trilobites within a collection of dinosaurs: Using the Royal Tyrrell Museum of Palaeontology to document Cambrian predation // Palaeontologia Electronica. Vol.23. No.2. P.a33.

Bicknell R.D.C., Pates S., Botton M.L. 2018. Abnormal xiphosurids, with possible application to Cambrian trilobites. Palaeontologia Electronica. Vol.21. No.2. P.1-17.

Botton M.L., Loveland R.E. 1989. Reproductive risk: high mortality associated with spawning by horseshoe crabs (Limulus polyphemus) in Delaware Bay, USA // Marine Biology. Vol.101. No.2. P.143-151.

Chatterji A., Rathod V., Parulekar A.H. 1988. Growth and morphometric characteristics in the horse-shoe crab, Carcinoscorpius rotundicauda (Latreille) from Canning (West Bengal), India // Pakistan Journal of Scientific and Industrial Research. Vol.31. No.5. P.352-353.

Chatterji A., Parulekar A.H. 1992. Fecundity of the Indian horseshoe-crab, Carcinoscorpius rotundicauda (Latreille) // Tropical Ecology. Vol.33. No.1. P.97-102.

Chatterji A., Rathod V., Parulekar A.H. 1992a. Seasonal variation in the volume of heamolymph \& body weight of Tachypleus gigas (Müller) // Pakistan Journal of Scientific and Industrial Research, Vol.35. P.495-498.

Chatterji A., Rathod V., Parulekar A.H. 1992b. Spawning migration of the horseshoe crab, Tachypleus gigas (Müller), in relation to lunar cycle // Asian Fisheries Science. Vol.5. P.123128 .

Chatterji A., Mishra J.K., Parulekar A.H. 1992c. Feeding behaviour and food selection by Tachypleus gigas (Müller) // Hydrobiologia. Vol.246. P.41-48.

Chatterji A., Abidi S.A.H. 1993. The Indian horseshoe crab: A living fossil // Journal of Indian Ocean Studies. Vol.1. No.1. P.43-48.

Chatterjee A., Mishra J.K., Vijayakumar R., Parulekar A.H. 1994 Length-weight relationship of the Indian horseshoe crab Tachypleus gigas (Müller) // Indian Journal of Fisheries. Vol.41. No.2. P.111-113.

Chatterji A., Parulekar A.H., Qasim S.Z. 1996a. Nesting behaviour of the Indian horseshoe crab, Tachypleus gigas (Müller) (Xiphosura) // Qasim S.Z., Roonwal G.S. (eds.). India's Exclusive Economic Zone: Resources, Exploitation, Management. New Delhi: Omega Scientific Publication. P.142-152.

Chatterji A., Aguiar Q., Saldanha C. 1996b. Energy source in the developing eggs of the Indian horseshoe crab, Tachypleus gigas (Müller) // Journal of Aquaculture in Tropics. Vol.11. P.271-276.

Chatterji A. 1999. New record of the sympatric distribution of two Asian species of the horseshoe crab // Current Science. Vol.77. P.746-747.

Chatterji A., Alam H., Joshi B.K., Bhonde R.R. 2004a. Regeneration of gill lamellae of the Indian horseshoe crab, Tachypleus gigas (Müller) // Current Science. Vol.87. No.11. P.15111512.

Chatterji A., Kotnala S., Mathew R. 2004b. Effect of salinity on larval growth of horseshoe crab, Tachypleus gigas (Müller) // Current Science. Vol.87. No.2. P.248-250.

Chatterji A., Shaharom F. 2009. Unusual spawning behaviour of the horseshoe crab (Tachypleus gigas, Müller) after the tsunami along Orissa coast, India // Pertanika Journal of Science and Technology. Vol.17. P.263-268.

Chaudhuri P.S., Nanda D.K., Debnath R. 1991.Cytomorphic studies on the neurosecretory cells in the central nervous system of the Indian horseshoe crab Carcinoscorpius rotundicauda (Latreille) // Functional and Developmental Morphology. Vol.1. No.1. P.13-16.
Chen C.P., Yeh H.Y., Lin P.F. 2004. Conservation of the horseshoe crab at Kinmen, Taiwan: strategies and practices // Biodiversity and Conservation. Vol.13. No.10. P.1889-1904.

Debnath R., Choudhury A. 1988a. Length-weight relationship of the living-fossil Carcinoscorpius rotundicauda (Latreille) (Merostomata: Xiphosura) of Sundarbans Estuary, India // Environment and Ecology. Vol.6. No.4. P.923-927.

Debnath R., Choudhury A. 1988b. Population estimation of horseshoe crab Tachypleus gigas by capture-recapture method at Chandipur sea shore (Odisha), India // Journal of Marine Biology Association of India. Vol.30. No.1-2. P.8-12.

Debnath R., Choudhury A. 1988c. Predation of Indian horseshoe crab, Tachypleus gigas by Corvus splendens // Tropical Ecology. Vol.29. No.2. P.86-89.

Debnath R., Choudhury A. 1989. Geographic distribution of Indian horseshoe crabs (Merostomata: Xiphosura) in the coastal water of Bay of Bengal, India // Journal of Bengal Natural History Society. Vol.8. No.2. P.30-35.

Debnath R., Choudhury A. 1991. Comparative assessment of two breeding populations of crabs Tachypleus gigas (Müller) (Merostomata: Xiphosura) // Environment \& Ecology. Vol.9. No.1. P.163-166.

Debnath R., Choudhury A. 1992. Length-weight relationship of the living fossil, Tachypleus gigas (Merostomata: Xiphosura) // Acta Zoologica Bulgarica. Vol.44. P.70-74.

Debnath R., Choudhury A. 1996. Rare occurrence of tandem amplexus by male Indian horseshoe crabs, Carcinoscorpius rotundicauda, with a comment on mating in Limulidae (Merostomata: Xiphosura) // Advances in Biosciences. Vol.15. P.103107.

Debnath R., Nag S.K., Choudhury A., Dasgupta R., Sur R.K. 1989. Feeding habit and digestive physiology of the Indian horseshoe crab, Tachypleus gigas (Müller) // Indian Journal of Physiological \& Allied Science. Vol.43. No.2. P.44-49.

Debnath R. 1991. Studies on species morphology and sexual dimorphism of Indian horseshoe crabs // Geobios New Reports. Vol.10. P.128-131.

Ghosh A., Schmidt S., Fickert T., Nüsser M. 2015. The Indian Sundarbans mangrove forests: history, utilization, conservation strategies and local perception // Diversity. Vol.7. No.2. P.149-169.

Itow T., Mishra J.K., Ahmed A.T. 2004. Horseshoe crab (King $\mathrm{Crab}$ ) in the Bay of Bengal, South Asia // Bulletin of the Education Faculty, Shizuka University, Natural Science Series. Vol.54. P.13-30.

Jana S. 2020. Micro-level coastal vulnerability assessment in relation to post-Aila landscape alteration at the fragile coastal stretch of the Sagar Island, India // Regional Studies in Marine Science. Vol.33. P.100908.

Jell P.A. 1989. Some aberrant exoskeletons from fossil and living arthropods // Memoirs of the Queensland Museum. Vol.27. No.2. P.491-498.

Keinath JA. 2003. Predation of horseshoe crabs by loggerhead turtles // Shuster C.N., Jr., Barlow R.B., Brockmannm H.J. (eds.). The American Horseshoe Crab. Cambridge: Harvard Press. P.152-153.

Khan R.A. 2003. Observation on some aspects of the biology of horseshoe crab, Carcinoscorpius rotundicauda (Latreille) on mud flats of Sundarban Estuarine Region // Records of the Zoological Survey of India. Vol.101. P.1-23.

Kuehl S.A., Allison M.A., Goodbred S.L., Kudrass H.E. 2005. The Ganges-Brahmaputra Delta // Special Publication-SEPM. Vol.83. P.413.

Latreille P.A. 1802. Histoire naturelle générale et particulière des crustacés et insectes. Vol.3. Families naturelles et generes. Paris: Dufart. 467 p.

Leach W.E. 1819. // Dictionnaire des Sciences Naturelle. Paris. Vol.14. P. 537-538.

Linnaeus C. 1758. Systema Naturæ per Regna Tria Naturæ: Secundum classes, ordines, genera, species, cum characteribus, differentiis, synonymis, locis. 10th edition. Vol.1. Stockholm: Laurentius Salvius. 823 p. 
Mikhailov V.N., Dotsenko M.A. 2007. Processes of delta formation in the mouth area of the Ganges and Brahmaputra rivers // Water Resources. Vol.34. No.4. P.385-400.

Mirshahi M., Alam H., Mirshahi P., Soria J., Therwath A., Chatterji A. 2011. Role of Peri-vitelline fluid of the fertilized eggs of Indian horseshoe crab promoting wound healing process // Journal of Coastal Environment. Vol.2. No.2. P.159-166.

Mishra J.K., Chatterji A., Parulekar A.H. 1993. A freak twin trilobite larva of the Indian horseshoe crab Tachypleus gigas (Müller) // Journal of Bombay Natural History Society. Vol.90. No.1. P.116-117.

Mishra J.K. 2009a. Horseshoe crabs, their eco-biological status along the northeast coast of India and the necessity for ecological conservation // Tanacredi J.T., Botton M.L., Smith D.R. (eds.). Biology and Conservation of Horseshoe Crabs. Boston, MA: Springer. P.89-96.

Mishra J.K. 2009b. Larval culture of Tachypleus gigas and its molting behaviour under laboratory condition // Tanacredi J.T., Botton M.L., Smith D.R. (eds.). Biology and Conservation of Horseshoe Crabs. Boston, MA: Springer. P.513-519.

Mitra A.S. Srimal K.L., Choudhury A., Bhattacharyya D.P. 2000. Copper concentration in water, sediment and haemolymph of horseshoe crab in deltaic Sundarban, India // Proceedings of the Zoological Society of Calcutta. Vol.53. No.2. P.84-87.

Mondal I., Bandyopadhyay J., Chakrabarti P., Santra D. 2015. Morphodynamic change of Fraserganj and Bakkhali coasta stretch of Indian Sundarbans, South 24 Parganas, West Bengal, India // International Journal of Remote Sensing Applications. Vol.5. P.1-10

Müller O.F. 1785. Entomostraca seu Insecta Testacea. P.124-126. Leipzig and Copenhagen.

Nandi S., Ghosh M., Kundu A., Dutta D., Baksi M. 2015. Shoreline shifting and its prediction using remote sensing and GIS techniques: a case study of Sagar Island, West Bengal (India) // Journal of Coastal Conservation. Vol.20. No.1. P.61-80.

Naugolnykh S.V. 2018. Main biotic and climatic events in Early Permian of the Western Urals, Russia, as exemplified by the shallow-water biota of the early Kungurian lagoons // Palaeoworld. Vol.29. No.2. P.391-404.

Owen A.W. 1985. Trilobite abnormalities // Transactions of the Royal Society of Edinburgh: Earth Sciences. Vol.76. No.2-3. P.255-272.

Pates S., Bicknell R.D.C. 2019. Elongated thoracic spines as potential predatory deterrents in olenelline trilobites from the lower Cambrian of Nevada // Palaeogeography, Palaeoclimatology, Palaeoecology. Vol.516. P.295-306

Patil J.S., Anil A.C. 2000. Epibiotic community of the horseshoe crab Tachypleus gigas // Marine Biology. Vol.136. P.699713.

Rama Rao K.V., Surya Rao K.V. 1972. Studies on Indian King crabs (Arachnida: Xiphosura) // Proceeding of Indian National Science Academy. Vol.38. No.3/4. P.206-211.

Roonwal M.L. 1944. Some observations on the breeding biology, and on the swelling, weight, water content and embryonic movements in the developing, eggs, of the moluccan kingcrab, Tachypleus gigas (Müller) (Arthropoda: Xiphosura) // Proceedings of the Indian Academy of Sciences-Section B. Vol.20. No.4. P.115-129.

Rudkin D.M., Young G.A., Nowlan G.S. 2008. The oldest horseshoe crab: a new xiphosurid from Late Ordovician KonservatLagerstätten deposits, Manitoba, Canada // Palaeontology. Vol.51. No.1. P.1-9.
Rudra K. 2014. Changing river courses in the western part of the Ganga-Brahmaputra delta // Geomorphology. Vol.227. P.87100.

R Development Core Team. 2020. R: A Language and Environment for Statistical Computing. R Foundation for Statistical Computing, Vienna, Austria. https://www.R-project.org/

Saha D. 1987. Biological studies on horseshoe crabs (Merostomata: Xiphosura, Xiphosuriade) of Indian Region // Journal of the Indian Society of Coastal Agriculture Research. Vol.5. No.1. P.347-351.

Sahu A.C., Dey L. 2013. Spawning density and morphometric characteristics of the horseshoe crab Tachypleus gigas (Müller) on the Balasore coast of Bay of Bengal, India // Science Vision. Vol.13. No.2. P.76-84.

Sekiguchi K., Nakamura K., Sen T.K., Sugita H. 1976. Morphological variation and distribution of a horseshoe crab, Tachypleus gigas, from the Bay of Bengal and the Gulf of Siam // Proceedings of the Japanese Society of Systematic Zoology. Vol.12. P.13-20.

Sekiguchi K., Nakamura K., Seshimo H. 1978. Morphological variation of a horseshoe crab, Carcinoscorpius rotundicauda, from the Bay of Bengal and the Gulf of Siam // Proceedings of the Japanese Society of Systematic Zoology. Vol.15. P.24-30.

Sekiguchi K., Seshimo H., Sugita H. 1988. Post-embryonic development of the horseshoe crab // The Biological Bulletin. Vol.174. No.3. P.337-345.

Shuster C.N., Jr. 1982. A pictorial review of the natural history and ecology of the horseshoe crab Limulus polyphemus, with reference to other Limulidae // Progress in Clinical and Biological Research. Vol.81. P.1-52.

Tripathy B., Sivakumar K., Sajan J., Satyaranjan B., Choudhury B.C. 2013. Assessment of the population status and threats to the horseshoe crabs along the northern east coast of India // Venkataraman K., Sivaperuman C., Raghunathan C.(eds.). Ecology and Conservation of Tropical Marine Faunal Communities. Berlin, Heidelberg: Springer. P.137-146.

Tripathy B., Sivakumar K.S., Sett T. 2014. Biology and conservation of horseshoe crabs of India - A bibliographical review for identifying gap areas of research. Kolkata: Zoological Survey of India.

Tripathy B., Mohapatra A., Mukhopadhyay A.K. 2018. Status survey of horseshoe crabs along the East Coast of India // Status Survey Report, Published by the Director, Zoological Survey India, Kolkata. Vol.13. P.1-109.

Umitsu M. 1993. Late Quaternary sedimentary environments and landforms in the Ganges Delta // Sedimentary Geology. Vol.83. No.3-4. P.177-186.

van der Meer Mohr J.C. 1935. Sur quelques malformations chez la limule, Tachypleus gigas // Miscellanea Zoologica Sumatrana. Vol.87. P1-3.

Van Roy P., Orr P.J., Botting J.P., Muir L.A., Vinther J., Lefebvre B., El Hariri K., Briggs D.E.G. 2010. Ordovician faunas of Burgess Shale type // Nature. Vol.465. No.7295. P.215-218.

Vijayakumar R., Das S., Chatterji A., Parulekar A.H. 2000. Morphometric characteristics in the horseshoe crab Tachypleus gigas (Arthropoda: Merostomata) // Indian Journal of Marine Sciences. Vol.29. P.333-335.

Responsible editor K.G. Mikhailov 